\title{
Co-Mn-Al Mixed Oxides Promoted by K for Direct NO Decomposition: Effect of Preparation Parameters
}

\author{
Kateřina Pacultová ${ }^{1, *(\mathbb{D}}$, Tereza Bílková ${ }^{1,2}$, Anna Klegova ${ }^{1}$, Kateřina Karásková ${ }^{1}$, \\ Dagmar Fridrichová ${ }^{1,3}$, Květa Jirátová ${ }^{4}$, Tomáš Kiška ${ }^{1,2}$, Jana Balabánová ${ }^{4}$, Martin Koštejn ${ }^{4}$, \\ Andrzej Kotarba ${ }^{5}\left(\mathbb{D}\right.$, Wojciech Kaspera ${ }^{5}$, Paweł Stelmachowski ${ }^{5} \mathbb{D}$, Grzegorz Słowik ${ }^{6}$ and \\ Lucie Obalová ${ }^{1}$ (D) \\ 1 Institute of Environmental Technology, VŠB-Technical University of Ostrava, 17. listopadu 15/2172, \\ CZ-70800 Ostrava-Poruba, Czech Republic \\ 2 Faculty of Material Science and Technology, VŠB-Technical University of Ostrava, 17. listopadu 15/2172, \\ CZ-70800 Ostrava-Poruba, Czech Republic \\ 3 Centre ENET, VŠB-Technical University of Ostrava, 17. listopadu 15/2172, CZ-70800 Ostrava-Poruba, \\ Czech Republic \\ 4 Institute of Chemical Process Fundamentals of the CAS, v.v.i., Rozvojová 2/135, CZ-16501 Praha 6-Suchdol, \\ Czech Republic \\ 5 Faculty of Chemistry, Jagiellonian University, Gronostajowa 2, PL-30387 Krakow, Poland \\ 6 Faculty of Chemistry, Department of Chemical Technology, Maria Curie-Skłodowska University, \\ Plac Marii Curie-Skłodowskiej 3, PL-20-031 Lublin, Poland \\ * Correspondence: katerina.pacultova@vsb.cz; Tel.: +420-597-327-327
}

Received: 27 May 2019; Accepted: 3 July 2019; Published: 9 July 2019

\begin{abstract}
Fundamental research on direct NO decomposition is still needed for the design of a sufficiently active, stable and selective catalyst. Co-based mixed oxides promoted by alkali metals are promising catalysts for direct NO decomposition, but which parameters play the key role in NO decomposition over mixed oxide catalysts? How do applied preparation conditions affect the obtained catalyst's properties? $\mathrm{Co}_{4} \mathrm{MnAlO}_{\mathrm{x}}$ mixed oxides promoted by potassium calcined at various conditions were tested for direct $\mathrm{NO}$ decomposition with the aim to determine their activity, stability and selectivity. The catalysts were prepared by co-precipitation of the corresponding nitrates and subsequently promoted by $\mathrm{KNO}_{3}$. The catalysts were characterized by atomic absorption spectrometry (AAS)/inductive coupled plasma (ICP), X-ray photoelectron spectrometry (XPS), XRD, $\mathrm{N}_{2}$ physisorption, temperature programmed desorption of $\mathrm{CO}_{2}\left(\mathrm{TPD}-\mathrm{CO}_{2}\right)$, temperature programmed reduction by hydrogen (TPR- $\mathrm{H}_{2}$ ), species-resolved thermal alkali desorption (SR-TAD), work function measurement and STEM. The preparation procedure affects physico-chemical properties of the catalysts, especially those that are associated with the potassium promoter presence. The addition of $\mathrm{K}$ is essential for catalytic activity, as it substantially affects the catalyst reducibility and basicity-key properties of a deNO catalyst. However, SR-TAD revealed that potassium migration, redistribution and volatilization are strongly dependent on the catalyst calcination temperature-higher calcination temperature leads to potassium stabilization. It also caused the formation of new phases and thus affected the main properties $-S_{\mathrm{BET}}$, crystallinity and residual potassium amount.
\end{abstract}

Keywords: nitric oxide; catalytic decomposition; potassium promoter; cobalt-based mixed oxide

\section{Introduction}

Nitrogen oxides $\left(\mathrm{NO}_{\mathrm{x}}\right)$ are produced by anthropogenic activities, mainly by combustion of fossil fuels in automotive engines and power plants. NO accounts for more than $95 \%$ of these nitrogen oxides emissions [1]. Nowadays, there are two types of technologies that help to reduce NO 
emissions-selective catalytic reduction (SCR) and selective non-catalytic reduction (SNCR). However, in both these processes, a reducing agent (ammonia, urea) has to be used. NO can also be decomposed directly to $\mathrm{N}_{2}$ and $\mathrm{O}_{2}$. The disadvantage of this simple method is that the reaction takes place at high temperature $\left(>1100^{\circ} \mathrm{C}\right)$ due to the high value of activation energy $(\sim 335 \mathrm{~kJ} / \mathrm{mol})$ [2]. High activation energy of $\mathrm{NO}$ decomposition can be decreased by the presence of a suitable catalyst.

Many catalysts for direct NO decomposition have been tested; however, none of them have been sufficiently stable, active and selective at economically feasible temperatures yet. The studied catalysts are mainly based on precious metals $(\mathrm{Pt}, \mathrm{Pd}, \mathrm{Rh})[3-5]$, zeolites $[6-8]$ or single $[9,10]$ and mixed oxide catalysts [11-13]. The results suggest that further increase in catalytic activity would be difficult to achieve with metals or alloys alone or simple metal oxides. A more active system requires the presence of different kind of active sites necessary for each individual step of the NO decomposition reaction, such as NO adsorption, surface reaction of intermediates and oxygen and nitrogen desorption [14,15]. These can be obtained for example in mixed oxides systems.

Co-based mixed oxides promoted by alkali metals were used as catalysts for various reactions and they showed interesting results in NO decomposition $[9,11]$. From previous studies, it is known that alkali metals volatilize from transition metal oxides at temperatures higher than $500{ }^{\circ} \mathrm{C}$ [16-18], which could affect long-term stability of the catalyst [11]. The above mentioned results imply that the stability of alkali metal promoters has to be improved for viable application of these catalysts.

The literature showed that the alkali promoter stability could be improved by modifications of the preparation procedure. One possibility is changing the way of introducing an alkali metal into the catalyst (changing the catalyst bulk structure) during synthesis. The calcination procedure of catalyst precursors is another very important optimizing parameter, since calcination conditions (e.g., temperature, time) strongly influence the stability of alkali metal-containing catalysts. The advantage of high temperature calcination of $\mathrm{K} / \mathrm{Co}-\mathrm{Al}$ mixed oxide regarding $\mathrm{N}_{2} \mathrm{O}$ decomposition was published by Cheng [19]. The rearrangement of the surface alkali metal species depending on the calcination temperature leading to different stability of the obtained catalytic system was also reported elsewhere $[18,20]$.

For a tailored synthesis of an active catalyst, understanding the reaction mechanism is also important. Although several works have been devoted to the study of the $\mathrm{NO}_{\mathrm{x}}$ decomposition mechanism [2,21-23], details of the mechanisms and the exact nature of active sites, especially for NO catalytic decomposition on mixed oxides, are still a matter of debate, as well as the relationship between the method of preparation, physico-chemical properties and catalytic performance. The NO molecule can adsorb either dissociatively or molecularly depending on the type of active metal and on the conditions of adsorption; moreover, chemisorption of the reactants can cause adsorbate-induced reconstruction of the surface [2]. Dissociation of NO on the surface often depends on surface temperature, surface coverage, crystal plane and the concentration of surface defects [3]. Tsujimoto [24] along with Hong et al. [25] have recently demonstrated that control of the surface basicity of the catalyst is also important in terms of enhancing NO decomposition activity. An active catalyst should allow easy desorption of oxygen atoms from the catalyst surface, which is a very important reaction step. Moreover, catalysts with appreciable activity for direct NO decomposition should provide stronger adsorption of nitrogen compared to that of oxygen [26].

The above studies motivated us to prepare the $\mathrm{Co}-\mathrm{Mn}-\mathrm{Al}$ mixed oxide catalyst promoted by potassium to study its deNO catalytic properties more systematically. The bulk promotion method was used for modifying the catalyst by potassium, since it is supposed that incorporation of the promoter into the structure improves the promoter activity and stability [27]. The main objective was the enhancement of NO catalytic decomposition activity and stability through optimizing the conditions (calcination temperature and time) of the preparation method and the content of the alkali promoter.

The addition of potassium was proven to be important for catalyst activity. There is an optimal amount of $\mathrm{K}$ responsible for the formation of surface basic sites. The sufficient amount and right type of basic sites play a key role in direct NO decomposition, as well as optimal catalyst reducibility. 
The SR-TAD measurements clearly showed that potassium migration, redistribution and finally volatilization are directly linked to the catalyst calcination temperature.

\section{Results}

\subsection{Characterization of Catalysts}

\subsubsection{Chemical Composition}

The results of chemical analysis of selected fresh catalysts promoted by different amount of potassium, calcined at four different temperatures $\left(500,600,700\right.$ and $\left.800^{\circ} \mathrm{C}\right)$ and for two different time periods ( 4 and $12 \mathrm{~h}$ ) are summarized in Table 1 . The calculated molar ratio is close to the values set during preparation $\mathrm{Co}: \mathrm{Mn}: \mathrm{Al}=4: 1: 1$.

Table 1. Physicochemical properties of selected prepared catalysts.

\begin{tabular}{ccccc}
\hline Sample * $^{*}$ & $\begin{array}{c}\text { Co } \\
\text { (wt.\%) }\end{array}$ & $\begin{array}{c}\text { Mn } \\
\text { (wt.\%) }\end{array}$ & $\begin{array}{c}\text { Al } \\
\text { (wt.\%) }\end{array}$ & $\begin{array}{c}\text { Co:Mn:Al } \\
\text { (Molar Ratio) }\end{array}$ \\
\hline $\mathrm{K}(\mathrm{II}) / 500 / 4$ & 52.8 & 11.2 & 5.1 & $4.0: 0.9: 0.8$ \\
$\mathrm{~K}(\mathrm{II}) / 600 / 4$ & 49.7 & 11.9 & 5.4 & $4.0: 1.0: 1.0$ \\
$\mathrm{~K}(\mathrm{II}) / 700 / 4$ & 51.5 & 11.4 & 5.4 & $4.0: 1.0: 0.9$ \\
$\mathrm{~K}(\mathrm{II}) / 800 / 4$ & 45.1 & 12.0 & 5.6 & $4.0: 1.1: 1.1$ \\
$\mathrm{~K}(\mathrm{I}) / 500 / 12$ & 48.1 & 11.7 & 5.3 & $4.0: 1.0: 1.0$ \\
$\mathrm{~K}(\mathrm{II}) / 500 / 12$ & 44.2 & 11.3 & 5.1 & $4.0: 1.1: 1.0$ \\
$\mathrm{~K}(\mathrm{III}) / 500 / 12$ & 46.9 & 11.0 & 5.5 & $4.0: 1.0: 1.0$ \\
$\mathrm{~K}(\mathrm{IV}) / 500 / 12$ & 51.0 & 10.5 & 5.4 & $4.0: 0.9: 0.9$ \\
$\mathrm{~K}(0) / 600 / 4$ & 51.0 & 16.0 & 6.4 & $4.0: 1.3: 1.1$ \\
\hline
\end{tabular}

* Sample denotation: $\mathrm{K}(x) / y / z$, where $x$ means $\mathrm{K}$ content in $\mathrm{wt} . \%, y$ means calcination temperature $\left({ }^{\circ} \mathrm{C}\right)$ and $z$ means calcination time (h). For details, see Section 4.1.

Chemical analysis was also focused on the content of potassium, since its loss due to thermal vaporization was expected [28] (Table 2). A decrease of $\mathrm{K}$ concentration was observed with increasing calcination temperature and calcination time. While the increase in temperature from 500 to $600{ }^{\circ} \mathrm{C}$ caused almost no decrease in $\mathrm{K}$ amount, $20 \%$ of $\mathrm{K}$ weight was lost during calcination at 700 and $800{ }^{\circ} \mathrm{C}(4 \mathrm{~h})$. The prolonged calcination time also caused a small drop in $\mathrm{K}$ amount (see samples $\mathrm{K}(\mathrm{II}) / 500 / 4$ and $\mathrm{K}(\mathrm{II}) / 500 / 12$ ). It is important to notice that simply comparing the potassium content in $\mathrm{wt} . \%$ is not possible because of the associated oxygen release from the catalysts during calcination at high temperatures.

Table 2. Selected experimental parameters (K content, specific surface area, particle size and unit cell parameter) for the investigated fresh and used catalysts.

\begin{tabular}{ccccccc}
\hline Sample & $\begin{array}{c}\mathbf{K}_{\text {fresh }} \\
(\mathbf{w t .} \%)\end{array}$ & $\begin{array}{c}\mathbf{K}_{\text {used }} \\
(\mathbf{w t .} \%)\end{array}$ & $\begin{array}{c}S_{\text {BET fresh }} \\
\left(\mathbf{m}^{2} / \mathbf{g}\right)\end{array}$ & $\begin{array}{c}S_{\text {BET }} \text { used } \\
\left(\mathbf{m}^{2} / \mathbf{g}\right)\end{array}$ & $\begin{array}{c}\boldsymbol{L}_{\mathbf{c} \text { fresh }} \\
(\mathbf{n m})\end{array}$ & $\begin{array}{c}\boldsymbol{a}_{\text {fresh }} \\
(\mathbf{n m})\end{array}$ \\
\hline $\mathrm{K}(\mathrm{II}) / 500 / 4$ & 2.1 & 1.8 & 94 & 33 & 9 & $0.81163 \pm 0.00004$ \\
$\mathrm{~K}(\mathrm{II}) / 600 / 4$ & 2.0 & 2.0 & 72 & 23 & 12 & $0.81075 \pm 0.00007$ \\
$\mathrm{~K}(\mathrm{II}) / 700 / 4$ & 2.0 & 1.8 & 50 & 21 & 16 & $0.81485 \pm 0.00004$ \\
$\mathrm{~K}(\mathrm{II}) / 800 / 4$ & 1.6 & 1.4 & 23 & 16 & 28 & $0.81512 \pm 0.00004$ \\
$\mathrm{~K}(\mathrm{I}) / 500 / 12$ & 0.7 & 0.6 & 73 & 42 & 10 & $0.81079 \pm 0.00010$ \\
$\mathrm{~K}(\mathrm{II}) / 500 / 12$ & 1.9 & 1.8 & 87 & 32 & 13 & $0.81085 \pm 0.00011$ \\
$\mathrm{~K}(\mathrm{III}) / 500 / 12$ & 2.4 & 2.5 & 73 & 44 & 12 & $0.81051 \pm 0.00005$ \\
$\mathrm{~K}(\mathrm{IV}) / 500 / 12$ & 3.1 & 2.7 & 69 & 40 & 13 & $0.81051 \pm 0.00005$ \\
$\mathrm{~K}(0) / 600 / 4$ & 0 & 0 & 49 & 12 & 13 & $0.81210 \pm 0.00008$ \\
\hline
\end{tabular}

A small loss of $\mathrm{K}(12.5 \%)$ was also observed during the catalytic tests, which corresponds to the results published in our previous work [11]. However, this trend was surprisingly not confirmed for all 
sets of the catalysts (not shown), which can be caused by a non-homogenous distribution of potassium in the samples (caused by its bulk and surface migration and/or vaporization) and the complexity of potassium content determination.

\subsubsection{Textural Properties}

The surface area of all catalysts was examined using $\mathrm{N}_{2}$ physisorption (one point Brunauer-EmmettTeller (BET) method) and selected results are summarized in Table 2. The specific surface areas varied from 16 to $94 \mathrm{~m}^{2} / \mathrm{g}$ and from 12 to $44 \mathrm{~m}^{2} / \mathrm{g}$ for fresh and used catalysts, respectively. Specific surface area decreased with rising calcination temperature and calcination time as well. A decrease in surface area of about $20 \mathrm{~m}^{2} / \mathrm{g}$ was observed for each $100{ }^{\circ} \mathrm{C}$ jump in the temperature used for calcination. A sharp decrease of surface area was also observed after catalytic measurements.

Pore size distributions of the selected samples reflecting the effect of $\mathrm{K}$ amount, calcination time and calcination temperature are shown in Figure 1. The catalysts calcined at $500{ }^{\circ} \mathrm{C}$ showed unimodal pore size distribution with a maximum around $30 \mathrm{~nm}$. Longer calcination time did not affect pore size distribution of the catalysts (Figure 1a). Lower potassium amount caused a slight shift of pore sizes to higher values (Figure 1b). The same trend is visible in Figure 1c: After calcination at higher temperatures accompanied by a decrease in $\mathrm{K}$ amount, the pore size shifted to higher values along with the creation of new pores with diameters higher than $60 \mathrm{~nm}$. The trend corresponds to the decrease in surface area after calcination at higher temperatures and is probably connected with the collapse of smaller pores and coalescence of the larger ones.

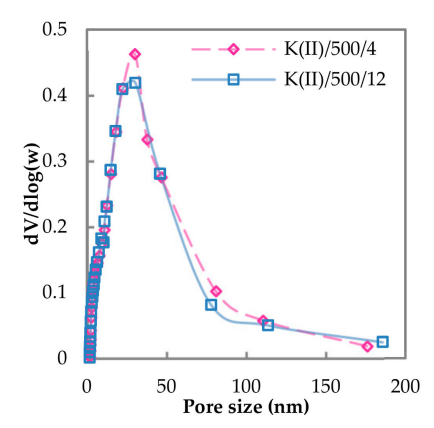

(a)

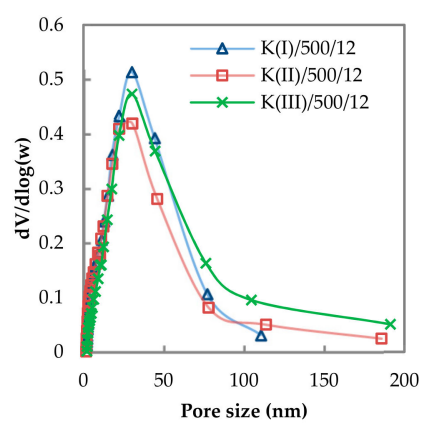

(b)

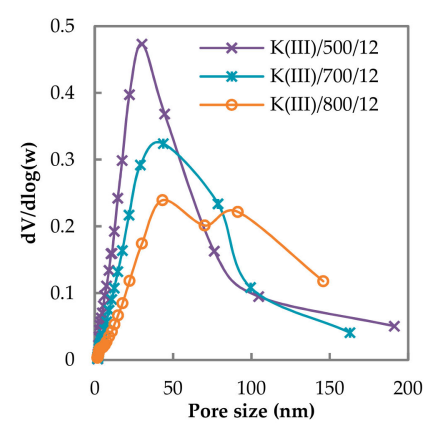

(c)

Figure 1. Pore size distribution of selected catalysts: (a) Effect of calcination time for samples K(II)/500/z, (b) effect of $\mathrm{K}$ amount for samples $\mathrm{K}(x) / 500 / 12$ and (c) effect of calcination temperature for samples $\mathrm{K}(\mathrm{III}) / y / 12$.

\subsubsection{Phase Composition}

Spinel-type mixed oxide phase was detected in all samples by X-ray powder diffraction analysis (Figures S1-S3 in Supplementary Materials). Very small diffraction line at about $38^{\circ}$ present in the samples calcined at lower temperatures can be ascribed to $\mathrm{Mn}_{2} \mathrm{O}_{3}$ (PDF-2 card No. 01-071-0636; see Supplementary Materials, Figures S1-S3) or can simply be an artifact of the measurement, K-beta line of the main spinel diffraction. Intensities of diffraction lines depend on the position of atoms in the spinel unit cell, while the position depends on the shape and size of the unit cell [29]. The ratio between spinel diffraction lines $(111) /(220)$ and $(220) /(444)$ is a measure of the occupancy of the tetrahedral cation sites [30,31]. In our case lattice parameter $a$ (Figure 2a), mean coherent domain size corresponding to crystallinity (Figure 2b), and (220)/(440) intensities ratio I (Figure 2c) increased with rising calcination temperature. All these parameters reflect the continuous process of gradual thermal crystallization of the spinel, i.e., continuous conversion of disordered material into well $\mathrm{X}$-ray diffracting oxides. 


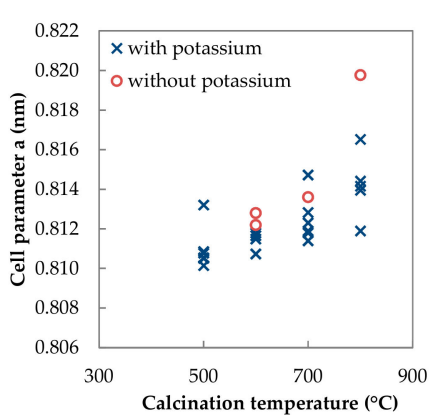

(a)

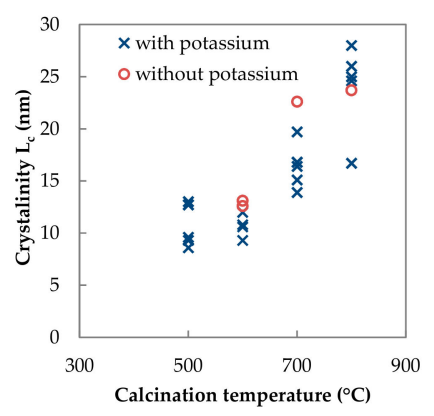

(b)

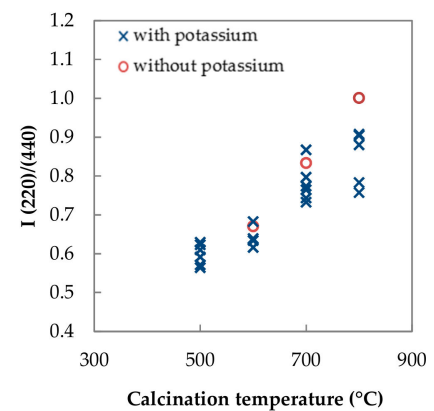

(c)

Figure 2. Effect of calcination temperature on (a) spinel lattice parameter $a$, (b) coherent domain size $L_{c}$ and (c) $I(220) /(440)$ intensities ratio.

The thermal behavior of a Co-Mn-Al mixed oxide system unmodified by potassium was previously described by Kovanda et al. [30]. They found that after decomposition of layered double hydroxides above $200-260^{\circ} \mathrm{C}$, nanocrystalline spinels are formed and spinels are the only phases present up to $900{ }^{\circ} \mathrm{C}$. However, at temperatures of about $500^{\circ} \mathrm{C}$ the segregation of $\mathrm{Co}$ rich spinel was observed, while the incorporation of manganese into the spinel lattice proceeded during its further recrystallization with increasing temperature accompanied by a lattice parameter increase, approaching the value typical for $\mathrm{Co}_{3} \mathrm{O}_{4}$ (samples calcined at $500{ }^{\circ} \mathrm{C}$ ) and the value typical for $\mathrm{Co}_{2} \mathrm{MnO}_{4}$ (samples calcined at $\left.800^{\circ} \mathrm{C}\right)$.

After careful inspection of the cell parameter changes, it was found out that $L_{c}$ and $a$ did not depend on the $\mathrm{K}$ amount for samples calcined at 500 and $600{ }^{\circ} \mathrm{C}$, while for samples calcined at 700 and especially at $800{ }^{\circ} \mathrm{C}$, the obvious dependence on potassium concentration could be observed (Figure 3a,b).

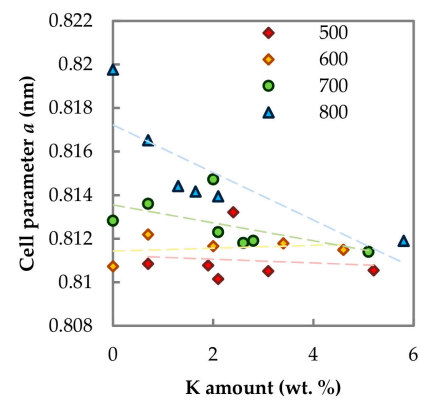

(a)

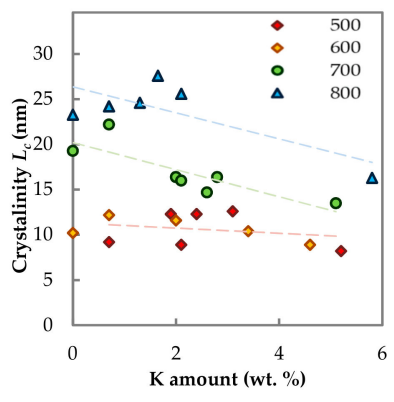

(b)

Figure 3. Dependence of (a) spinel lattice parameter $a$ on K amount and (b) crystallinity $L_{c}$ on K amount. The numbers in the legend mean the calcination temperature.

With increasing calcination temperature and/or higher amount of potassium, in addition to the spinel phase, a new phase containing potassium was also detected (Figures S1-S3 in Supplementary Materials). The nature and stoichiometry of the new phase depended on the temperature as well as on the potassium amount. Two different phases containing potassium were observed (Table 3)—cryptomelane $\mathrm{KMn}_{8} \mathrm{O}_{16}$ (molar ratio K/Mn = 0.13; PDF-2, card No. 00-006-0547), which was clearly distinguishable (marked as A) and another potassium manganese oxide phase (marked as B), which could be identified as $\mathrm{K}_{2} \mathrm{Mn}_{4} \mathrm{O}_{8}$ (PDF-2, card No. 00-016-0205) or $\mathrm{K}_{1,39} \mathrm{Mn}_{3} \mathrm{O}_{6}$ (PDF-2, card No. 01-080-7317), both having higher potassium/manganese molar ratio than cryptomelane $(\mathrm{K} / \mathrm{Mn}=0.5)$. The results of $\mathrm{X}$-ray diffraction (XRD) K-phase determination are shown in Table 3. Cryptomelane (A) was present in all samples calcined at $500^{\circ} \mathrm{C}$ and decomposed during calcination at above $600{ }^{\circ} \mathrm{C}$, forming the potassium manganese oxide phase (B). For the samples calcined at $600^{\circ} \mathrm{C}$, the type of present phase depended on 
the K content: For lower potassium amount cryptomelane was formed while for potassium amount higher that $1 \mathrm{wt} . \%$, the potassium manganese oxide phase was formed. The phase transformation depending on temperature for samples containing approximately $2 \mathrm{wt} . \%$ of potassium is illustrated in Figure S1 in the Supplementary Materials; the phase changes depending on potassium amount for samples calcined at 600 and $800{ }^{\circ} \mathrm{C}$ are illustrated in Figures S2 and S3, respectively. Longer calcination time did not affect the type of K-containing phase, only its degree of crystallinity (not shown). The changes observed for samples calcined below the catalytic reaction temperature (650 and/or $700{ }^{\circ} \mathrm{C}$ ) are in accordance with previous findings (Figures S1 and S2), since after the catalytic reaction, the potassium phase in A form was not present and only type B phases were observed in all tested samples (not shown).

Table 3. K-containing phases detected by XRD in Co-Mn-Al mixed oxide with different K-content and calcined at different temperatures (fresh samples).

\begin{tabular}{ccccc}
\hline \multirow{2}{*}{ Calcination Temperature $y\left({ }^{\circ} \mathrm{C}\right)$} & \multicolumn{5}{c}{ Sample } \\
\cline { 2 - 5 } & $\mathrm{K}(\mathrm{I}) / y / 4$ & $\mathrm{~K}(\mathrm{II}) / y / 4$ & $\mathrm{~K}(\mathrm{III}) / y / 4$ & $\mathrm{~K}(\mathrm{IV}) / y / 4$ \\
\hline 500 & $\mathrm{~A}$ & $\mathrm{~A}$ & $\mathrm{~A}$ & $\mathrm{~A}$ \\
600 & $\mathrm{~A}$ & $\mathrm{~A}$ & $\mathrm{~B}$ & n.d. \\
700 & $\mathrm{~B}$ & $\mathrm{~B}$ & $\mathrm{~B}$ & $\mathrm{~B}$ \\
800 & $\mathrm{~B}$ & $\mathrm{~B}$ & $\mathrm{~B}$ & $\mathrm{~B}$ \\
\hline
\end{tabular}

$\mathrm{A}-\mathrm{KMn}_{8} \mathrm{O}_{16}$ (cryptomelane), $\mathrm{B}-\mathrm{K}_{2} \mathrm{Mn}_{4} \mathrm{O}_{8}$ or $\mathrm{K}_{1,39} \mathrm{Mn}_{3} \mathrm{O}_{6}$, n.d.-not determined.

Based on the XRD findings described above, it can be concluded that potassium is bonded mainly to manganese. When there is not any potassium present in the sample or only a small amount, with increasing calcination temperature manganese enters the spinel lattice as can be inferred from the changes in lattice parameter, similarly as in a $\mathrm{K}$-free $\mathrm{Co}_{4} \mathrm{MnAlO}_{\mathrm{x}}$ spinel [28]. On the other hand, when a higher amount of potassium is present, more manganese is bonded to potassium and cannot enter the spinel lattice at higher calcination temperatures and for that reason, the lattice parameters returned to the values characteristic of the $\mathrm{Co}_{3} \mathrm{O}_{4}$ phase.

\subsubsection{Surface Composition}

The surface composition in the near-surface region and the chemical state of the elements over three selected samples was examined using X-ray photoelectron spectrometry (XPS). The following samples were chosen in order to elucidate the effect of potassium presence as well as the effect of calcination temperature:

(i) Sample without K,

(ii) Fresh sample modified by potassium calcined at $500^{\circ} \mathrm{C}$,

(iii) Used sample modified by potassium, which means that its structure corresponds to the sample calcined at $700{ }^{\circ} \mathrm{C}$ and can be changed somehow by catalytic reaction intermediates.

The surface concentrations of elements were determined (Table 4) from the intensities (peak areas) divided by the corresponding response factor [32]. Carbon correction was done for all samples. Apart from the main elements- $\mathrm{Co}, \mathrm{Mn}, \mathrm{Al}, \mathrm{K}$ and $\mathrm{Na}$-the elements $\mathrm{O}$ and $\mathrm{C}$ were also determined. The $\mathrm{K}(0) / 670 / 4$ catalyst contains 4.18 at. \% of $\mathrm{Na}$ on the surface. It remained in the catalyst after incomplete washing of the precipitate by distilled water. The catalyst K(II)/500/12 prepared by bulk promotion of the precipitate with $\mathrm{K}$ salt contains no $\mathrm{Na}$ and the finding indicates that the rest of sodium in the precipitate was interchanged with potassium during the bulk promotion procedure. The concentrations of oxygen and carbon on the surface were disregarded, and the atomic concentrations of metals were converted into weight percentages to compare them with the values obtained from inductive coupled plasma (ICP) analysis (Table 5). 
Table 4. Surface concentrations determined using X-ray photoelectron spectrometry (XPS) data evaluation in at. \%.

\begin{tabular}{cccccccc}
\hline \multirow{2}{*}{ Sample } & Co & Mn & Al & O & C & K & Na \\
\cline { 2 - 8 } & (at. \%) & (at. \%) & (at. \%) & (at. \%) & (at. \%) & (at. \%) & (at. \%) \\
\hline K(0)/670/4 & 9.08 & 4.55 & 7.66 & 44.41 & 30.12 & 0 & 4.18 \\
K(II)/500/12 & 9.37 & 4.07 & 8.25 & 44.26 & 30.99 & 3.07 & 0 \\
K(II)/500/12_used & 8.81 & 4.17 & 8.54 & 45.59 & 27.1 & 5.79 & 0 \\
\hline
\end{tabular}

Table 5. Comparison of bulk (from inductive coupled plasma (ICP)) and surface (from XPS) catalysts composition in wt.\%.

\begin{tabular}{|c|c|c|c|c|c|}
\hline \multirow{2}{*}{ Sample } & \multirow{2}{*}{$\begin{array}{c}\text { Co (wt.\%) } \\
\text { Bulk Surface }\end{array}$} & \multirow{2}{*}{$\frac{\text { Mn (wt.\%) }}{\text { Bulk Surface }}$} & \multirow{2}{*}{$\begin{array}{c}\text { Al (wt.\%) } \\
\text { Bulk Surface }\end{array}$} & \multirow{2}{*}{$\frac{\text { K (wt. } \% \text { ) }}{\text { Bulk Surface }}$} & \multirow{2}{*}{$\begin{array}{c}\text { Na (wt. } \%) \\
\text { Surface } \\
\end{array}$} \\
\hline & & & & & \\
\hline K0/670/4 & 49.2 & 11.7 & $5.4 \quad 19.0$ & $0.0 \quad 0$ & n.d. \\
\hline KII/500/12 & 45.6 & $11.0 \quad 0.0$ & 19.9 & $2.5 \quad 10.7$ & 0 \\
\hline KII/500/12_used & 44.0 & $10.1 \quad 19.0$ & 19.1 & 18.8 & 0 \\
\hline
\end{tabular}

As one can see from Table 5, the values of bulk and surface concentrations are not the same. The following relations between surface and bulk concentrations can be seen (Table 6): Compared to bulk content, surface of the catalysts shows identical concentration of cobalt, nearly twice as high concentration of manganese and substantially higher concentrations of aluminum and potassium (when it is present). The findings indicate that the catalyst particles contain equal cobalt concentration throughout the whole volume, which is not changed during catalyst use. The surface of the non-promoted catalyst is enriched by $\mathrm{Al}$ and $\mathrm{Mn}$. The fresh K-promoted catalyst shows four times higher $\mathrm{K}$ concentration on the surface than in the bulk and it means that $\mathrm{K}$ introduced by the bulk promotion method is located preferentially on the catalyst surface. The K, Mn and Al surface enrichment was also observed in our previous works [33,34].

Table 6. Ratio of weight percentages of surface and bulk concentrations of the metals.

\begin{tabular}{ccccc}
\hline \multirow{2}{*}{ Sample } & \multicolumn{4}{c}{ Surface/Bulk (Weight Ratio) } \\
\cline { 2 - 5 } & Co & Mn & Al & K \\
\hline $\mathrm{K}(0) / 670 / 4$ & 0.9 & 2.0 & 3.5 & 0 \\
$\mathrm{~K}(\mathrm{II}) / 500 / 12$ & 1.1 & 1.8 & 4.5 & 4.3 \\
$\mathrm{~K}(\mathrm{II}) / 500 / 12 \_$used & 1.0 & 1.9 & 3.8 & 9.9 \\
\hline
\end{tabular}

After the catalytic tests, further enrichment of the catalyst surface by K proceeds. The finding confirms gradual diffusion of $\mathrm{K}$ from the bulk of the catalyst due to its movement from lower parts of the catalyst particles to the surface during the tests at high reaction temperatures $\left(>650^{\circ} \mathrm{C}\right)$ and also subsequent volatilization since chemical analysis showed reduced concentration of $\mathrm{K}$ in the catalyst after catalytic tests.

$\mathrm{Co} 2 \mathrm{p}, \mathrm{Mn} 2 \mathrm{p}, \mathrm{Al} 2 \mathrm{p}, \mathrm{O} 1 \mathrm{~s}, \mathrm{~K} 2 \mathrm{p}$ and C 1s photoelectron spectra are presented in Figure S4 in Supplementary Materials for the K(0)/670/4, K(II)/500/12 and K(II)/500/12_used catalysts. In all samples, the deconvolution of the $\mathrm{Co} 2 \mathrm{p}_{3 / 2}$ region showed two peaks, main and satellite, with maxima at binding energy (BE) 780.5 and $786.4 \mathrm{eV}$.

Distinction between $\mathrm{Co}^{3+}$ and $\mathrm{Co}^{2+}$ is very difficult, as the difference between corresponding peaks is very small $\left(\mathrm{Co}^{3+}: 779.19-779.81 \mathrm{eV}, \mathrm{Co}^{2+}: 781.13-781.49 \mathrm{eV}\right.$ [35-40]). For identifying the cobalt chemical state, the energy separation of $2 \mathrm{p} 3 / 2$ to $2 \mathrm{p} 1 / 2$ and satellite structure of Co $2 \mathrm{p}$ spectra were used leading to the conclusion that both $\mathrm{Co}^{2+}$ and $\mathrm{Co}^{3+}$ chemical states are present. The shift of binding energies of $\mathrm{Co} 2 \mathrm{p} 3 / 2$ electrons towards higher values compared to $\mathrm{Co}_{3} \mathrm{O}_{4}(\mathrm{BE}=779.5 \mathrm{eV})$ could be related to the presence of other components (Al, Mn) [33]. 
Relative percentage of the Co $2 \mathrm{p}_{3 / 2}$ satellite peak (Table 7) correlates with $\mathrm{Co}^{2+}$. Therefore, $\mathrm{K}(\mathrm{II}) / 500 / 12$ used catalyst spectrum indicated the highest and $\mathrm{K}(0) / 670 / 4$ the lowest amount of $\mathrm{Co}^{2+}$. Manganese Mn 2 $\mathrm{p}_{3 / 2}$ spectra showed one maximum at $641.9 \mathrm{eV}$ indicating higher oxidation states. As the peak was quite broad, the catalysts consist of a mixture of at least two manganese states with $\mathrm{BE}$ corresponding to $\mathrm{Mn}_{3} \mathrm{O}_{4}$ and $\mathrm{MnO}_{2}$ [41]. Based on our previous research, $\mathrm{Mn} 2 \mathrm{p} 3 / 2$ was fitted by two peaks corresponding to $\mathrm{Mn}^{3+}(641.4-641.7 \mathrm{eV})$ and $\mathrm{Mn}^{4+}(642.6-642.9 \mathrm{eV})$ [33]. The data showed that $\mathrm{K}(\mathrm{II}) / 500 / 12$ used catalyst contained higher amount of $\mathrm{Mn}^{4+}$ than the others. Aluminum in all samples occurred in the form of $\mathrm{Al}^{3+}$.

Table 7. Binding energies and relative percentage (in parentheses) of fitted areas.

\begin{tabular}{|c|c|c|c|c|c|c|c|}
\hline \multirow{2}{*}{ Sample } & Co $2 p_{3 / 2}$ & $\operatorname{Co} 2 p_{3 / 2}$ sat. & $\operatorname{Mn} 2 p_{3 / 2}$ & $\operatorname{Mn} 2 p_{3 / 2}$ & O 1s & O 1s & O 1s \\
\hline & eV (\%) & eV (\%) & eV (\%) & eV (\%) & eV (\%) & eV (\%) & eV (\%) \\
\hline $\mathrm{K}(0) / 670 / 4$ & $780.5(82)$ & 786.4 (18) & $641.4(57)$ & $642.6(43)$ & $529.9(66)$ & $531.4(27)$ & $532.7(7)$ \\
\hline $\mathrm{K}(\mathrm{II}) / 500 / 12$ & $780.5(70)$ & $786.3(24)$ & $641.7(58)$ & $642.9(42)$ & $529.8(57)$ & $531.3(33)$ & $532.7(10)$ \\
\hline $\mathrm{K}(\mathrm{II}) / 500 / 12$ used & 780.5 (76) & $786.4(30)$ & $641.4(47)$ & $642.6(53)$ & $529.7(53)$ & $531.2(28)$ & $532.8(19)$ \\
\hline
\end{tabular}

Oxygen spectra were composed of three peaks at 529.91-529.61 (metal oxides), 531.42-531.13 (C-O single bond, $-\mathrm{OH}$ group) and 532.76-532.67 ( $\mathrm{C}=\mathrm{O}$ double bond) $\mathrm{eV}$. Approximately 50-60 relelative $\%$ of oxygen signal is formed by oxygen bonded to metals, but particular metal oxides were not possible to distinguish from the spectra. The rest of oxygen is bonded to carbon. For the samples containing potassium (both fresh and after catalytic tests) a change in the shape of the peaks can be seen. The changes indicate a slightly different oxidation state of metals.

Analysis of potassium in the fresh sample shows one state (BE $292.7 \mathrm{eV}$ for $\mathrm{K} 2 \mathrm{p}_{3 / 2}$ ); for the used sample, potassium shows two states (BE 292.7 and $294.8 \mathrm{eV}$ for K $2 \mathrm{p}_{3 / 2}$ ). The common state for both fresh and used samples is a $\mathrm{K}-\mathrm{Mn}-\mathrm{O}$ phase, while additional state of potassium in the used sample (BE $294.8 \mathrm{eV}$ ) can be ascribed to $\mathrm{K}$ oxidized slightly during the catalytic reaction.

Obtained results indicate that $\mathrm{K}$ is affecting the oxidation state of $\mathrm{Mn}$ and $\mathrm{Co}$ in spite of the finding that $\mathrm{K}$ is associated only with $\mathrm{Mn}$ in the potassium manganese oxide phase (XRD). The more $\mathrm{K}$ on the surface, the more $\mathrm{Co}^{2+}$ was found on the surface at the expense of $\mathrm{Co}^{3+}$, indicating that the presence of $\mathrm{K}$ causes the reduction of surface $\mathrm{Co}^{3+}$ to $\mathrm{Co}^{2+}$. Conversely, in the case of $\mathrm{Mn}$, the proportion of $\mathrm{Mn}^{4+}$ at the expense of $\mathrm{Mn}^{3+}$ increases with increasing $\mathrm{K}$ content on the surface, i.e., the presence of $\mathrm{K}$ causes oxidation of surface $\mathrm{Mn}^{3+}$ to $\mathrm{Mn}^{4+}$. This can be explained as follows: Since the amount of potassium located in the catalyst in the potassium manganese oxide phase was not determined, there can still be some amorphous potassium present in the vicinity of cobalt, which can influence the Co oxidation state. No potassium phases were found out via high-resolution transmission electron microscopy (HRTEM) imaging, which suggests that some potassium was present as amorphous species. Moreover, the catalyst consists of a mixed spinel oxide where both manganese and cobalt can be in different oxidation states. In case the state of manganese is changed e.g., by interaction with potassium, it will also cause a change in the cobalt oxidation state in the mixed oxide to maintain the neutrality and/or phase parameters. It is known [28] that potassium adsorption on metal surfaces results in substantial lowering of the surface potential on sites adjacent to a potassium atom, and a small, but still significant, lowering of the potential on sites located further away. The long-range effect is caused by a cumulative effect of all potassium atoms on the surface. The promotional effect of $\mathrm{K}$ has been already well described in the case of $\mathrm{N}_{2} \mathrm{O}$ catalytic decomposition over K-promoted Co-Mn-Al mixed oxides [42]. Potassium, due to its low ionization potential, enables the charge transfer to the transition metal cations inducing an electric field gradient at the surface generated by the resulting dipole and modification of the density of states characteristics. 


\subsubsection{Reducibility}

Reducibility of prepared catalysts was studied by temperature programmed reduction by hydrogen (TPR- $\mathrm{H}_{2}$ ). The TPR patterns of the selected fresh and used non-promoted and K-promoted catalysts are depicted in Figure 4. The non-promoted catalyst was reduced in two main temperature regions, $200-600{ }^{\circ} \mathrm{C}$ and $>600{ }^{\circ} \mathrm{C}$. The maximum temperature used during $\mathrm{TPR}-\mathrm{H}_{2}$ was $600{ }^{\circ} \mathrm{C}$ in order to avoid alkali vaporization and damage of the temperature conductivity detector (TCD)—for that reason only low temperature peaks can be visible and discussed. Both reduction maxima consist of overlapping peaks corresponding to the co-effect of several reducible species. The low-temperature peak represents the reduction of $\mathrm{Co}+\mathrm{II} \rightarrow \mathrm{Co}^{\mathrm{II}} \rightarrow \mathrm{Co}^{0}$ in the $\mathrm{Co}_{3} \mathrm{O}_{4}$-like phase and the reduction of $\mathrm{Mn}^{\mathrm{IV}}$ to $\mathrm{Mn}{ }^{\mathrm{III}}$ oxides. $\mathrm{Mn}^{\mathrm{III}} \rightarrow \mathrm{Mn}^{\mathrm{II}}$ reduction can takes place in both temperature regions [43]. In the K-promoted samples (Figure $4 \mathrm{~b}, \mathrm{c}$ ), the reduction of $\mathrm{K}$ containing phases in the low temperature region also cannot be excluded since the reduction of those species proceeds at temperatures between $200-450{ }^{\circ} \mathrm{C}$ [44-46]. The high temperature peak was attributed in the literature to the reduction of Co and $\mathrm{Mn}$ ions surrounded by $\mathrm{Al}$ ions in a spinel-like phase [47] and to the reduction of $\mathrm{Mn}^{\mathrm{III}}$.

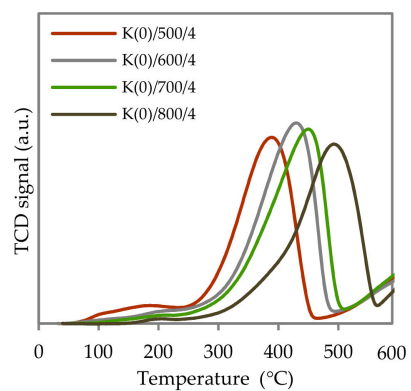

(a)

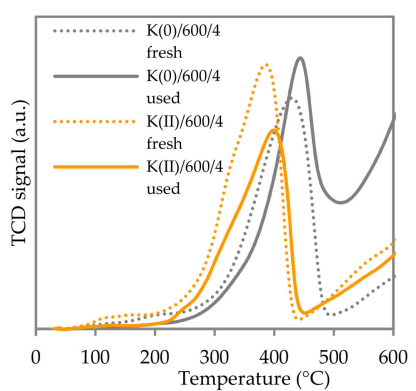

(b)

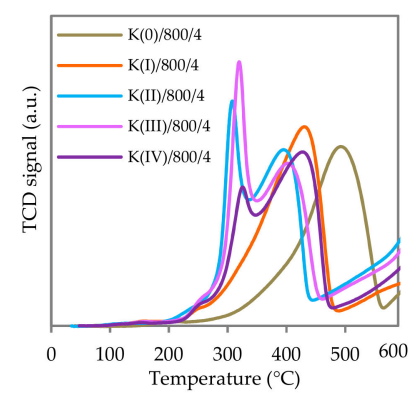

(c)

Figure 4. TPR- $\mathrm{H}_{2}$ results of (a) non-promoted samples calcined at 500-800 ${ }^{\circ} \mathrm{C}$, (b) fresh (dashed lines) and used potassium non-promoted and promoted samples calcined at $600{ }^{\circ} \mathrm{C}$ and (c) fresh samples calcined at $800^{\circ} \mathrm{C}$ containing different amount of $\mathrm{K}$.

For non-promoted samples, the different calcination temperature affected the position of the main low-temperature peak and showed different behavior compared to the promoted samples. While in both cases the low temperature peak shifted a little to higher temperatures for all samples due to the catalytic reaction, the peak increased after the catalytic reaction for non-promoted samples, in contrast to K-promoted samples where the peak area and especially the area of the low-temperature peak decreased after catalytic testing (Figure $4 b$ ).

The effect of the $\mathrm{K}$ amount for fresh samples calcined at $800^{\circ} \mathrm{C}$ is shown in Figure $4 \mathrm{c}$ and for used samples calcined at $500^{\circ} \mathrm{C}$ it is shown in Figure S5 in Supplementary Materials. The term "used samples" means that they underwent $\mathrm{NO}$ catalytic decomposition tests, i.e., in a state corresponding to calcination at $700{ }^{\circ} \mathrm{C}$ and influenced by the course of $\mathrm{NO}$ decomposition reaction as well. The modification of the $\mathrm{Co}-\mathrm{Mn}-\mathrm{Al}$ mixed oxide by potassium caused significant changes in the obtained reduction profiles. With increasing K content, a shift to lower temperatures accompanied by the broadening and subsequent splitting of the peak into two was observed (Figure 4c). New low temperature maximum appeared at around $300^{\circ} \mathrm{C}$. However, the trend of the new low temperature maximum differs depending on the calcination temperature. For used samples (corresponding to calcination temperature $700{ }^{\circ} \mathrm{C}$ ), the peak shifted to lower temperatures with increasing amount of potassium. In the case of samples calcined at $800^{\circ} \mathrm{C}$, the peak shifted to lower temperatures at first and then moved back to higher temperatures. The maxima of the main peak shifted to lower temperatures with increasing K amount (Figure S6 in Supplementary Materials) regardless of the used calcination temperature.

The effect of calcination temperature on catalysts reducibility while maintaining the same $\mathrm{K}$ amount was also observed. With increasing calcination temperature, the low-temperature peak shifted 
to higher temperatures, and started dividing into two with low temperature maximum at around $300{ }^{\circ} \mathrm{C}$ (Figure S7). A different situation was observed for the samples containing the lowest amount of $\mathrm{K}(\mathrm{K}(\mathrm{I})$ series), where no apparent changes related to calcination temperature were observed (Figure S8).

\subsubsection{Basicity}

Catalyst basicity is an important factor influencing chemical reactivity towards $\mathrm{NO}$ because of the acidic nature of the $\mathrm{NO}$ molecule [48]. In the temperature programmed desorption of $\mathrm{CO}_{2}\left(\mathrm{TPD}-\mathrm{CO}_{2}\right)$ profile, several types of basic sites in mixed oxides were reported. Weak basic sites represent $-\mathrm{OH}$ groups on the surface of the catalyst, medium sites consist of oxygen in $\mathrm{Me}^{2+}-\mathrm{O}^{2-}, \mathrm{Me}^{3+}-\mathrm{O}^{2-}$ pairs and strong basic sites correspond to the isolated $\mathrm{O}^{2-}$ anions [49]. However, strict separation of individual peaks above $140^{\circ} \mathrm{C}$ reflecting the presence of medium $\left(140-220^{\circ} \mathrm{C}\right)$ or strong $\left(>270{ }^{\circ} \mathrm{C}\right)$ basic sites is not common in the literature.

TPD- $\mathrm{CO}_{2}$ measurements were performed with the aim to find differences in basicity of the prepared catalysts. Since the catalytic activity achieved at a steady state is closer to the state of the used sample (sample after catalytic reaction) than to the sample in the fresh state, the amount and type of basic sites were mainly studied on the used samples. The comparison of the TPD- $\mathrm{CO}_{2}$ profile of fresh and used catalysts is shown in Figure $5 \mathrm{a}$. The effect of calcination temperature and potassium content on the amount of basic sites is shown in Figure 5b,c.

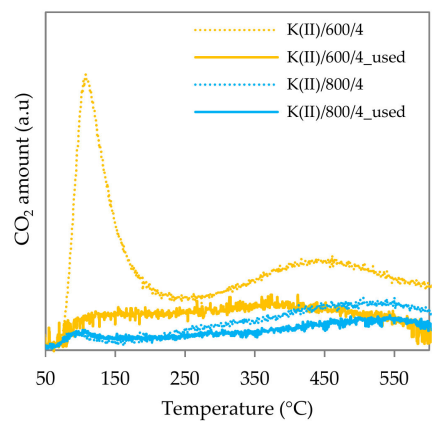

(a)

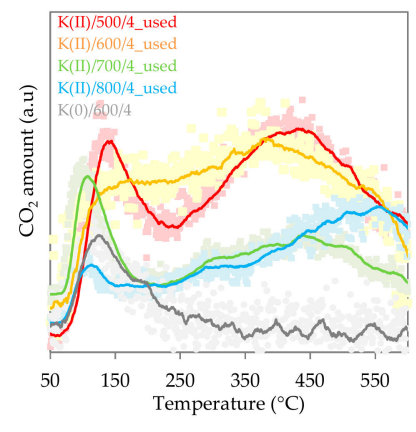

(b)

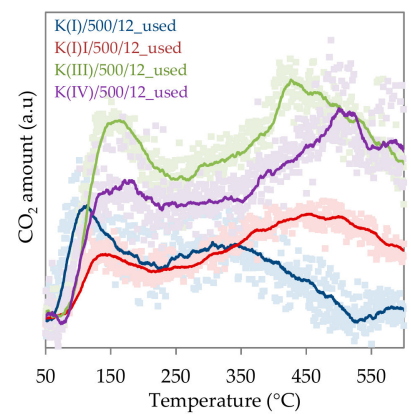

(c)

Figure 5. Temperature programmed reduction (TPD) $\mathrm{CO}_{2}$ results: (a) Fresh (dashed line) and used (full line) samples calcined at 600 or $800{ }^{\circ} \mathrm{C}$ for $4 \mathrm{~h}$, (b) effect of calcination temperature over $\mathrm{K}(\mathrm{II}) / y / 4$ _used samples calcined at different temperatures and (c) effect of $\mathrm{K}$ amount over used samples $\left(\mathrm{K}(x) / 500 / 12 \_\right.$used) calcined at $500{ }^{\circ} \mathrm{C}$ for $12 \mathrm{~h}$.

In the TPD profiles of our samples, the presence of all types of basic sites was clear or observable but in line with literature results, making a strict distinction was also not possible in our case; even more than three types of sites could be visible in some cases. The sample without the K promoter contains only weak basic sites (Figure 5b), and their amount is much lower than on fresh K-promoted samples. The amount of basic sites changed after the catalytic reaction. The used samples also had a lower amount of medium and strong basic sites in comparison with fresh samples and the type of sites has also changed - the temperature maxima of medium and strong basic sites are lower for the used samples. The most noticeable difference can be seen for the K(II)/600/4 fresh sample containing significant amount of weak basic sites, which disappeared after calcination at a higher temperature and also after the catalytic reaction. This can be explained by the fact that samples calcined at temperatures lower than the reaction temperature were re-calcined during the catalytic tests, so the changes reflect not only reaction-induced changes (the presence of intermediates and reaction products on the surface) but also temperature-induced structural changes observed by XRD and TPR- $\mathrm{H}_{2}$.

It was found out for all measured samples that the amount of medium and strong basic sites expressed as area under TPD-CO $\mathrm{CO}_{2}$ curve from the given temperature up to the end of desorption $\left(600^{\circ} \mathrm{C}\right)$ was linearly dependent on the total amount of basic sites (Figure 6a). The $\mathrm{CO}_{2}$ consumption 
decreased with increasing calcination temperature (Figure $6 \mathrm{~b}$ ) and increased with increasing amount of potassium (Figure 6c). From Figure $6 \mathrm{c}$ it can be deduced that potassium (0-3.1 wt.\%) linearly influenced the amount of basic sites determined in the temperature range higher than $250-400{ }^{\circ} \mathrm{C}$ (the intercept of the regression line is almost zero), which is in agreement with our previous work [34].

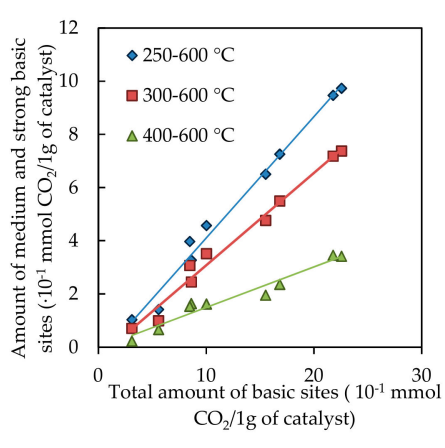

(a)

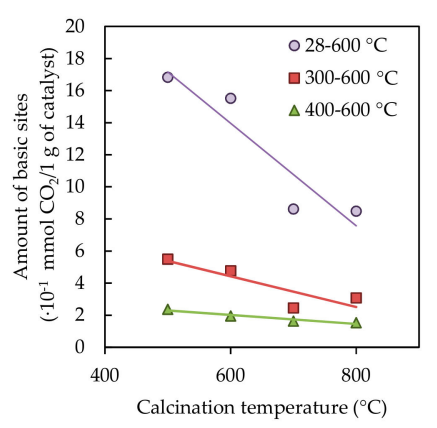

(b)

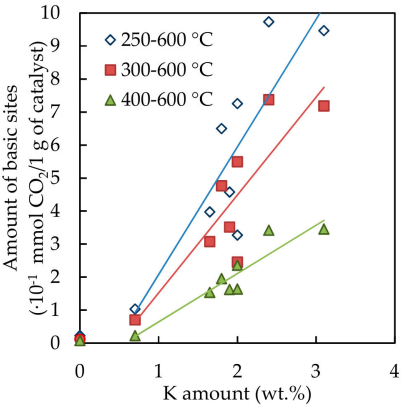

(c)

Figure 6. TPD $\mathrm{CO}_{2}$ results: (a) Dependence of the amount of medium and strong basic sites on the total amount of basic sites in temperature range of $0-600{ }^{\circ} \mathrm{C},(\mathbf{b})$ dependence of the amount of basic sites on the calcination temperature and (c) dependence of the amount of basic sites on the potassium amount. Numbers in legend mean temperature region from which the amount of sites was calculated.

\subsubsection{Phase Composition and Surface Elementary Mapping-TEM and STEM-EDS Analyses}

Places with diffraction patterns typical for $\mathrm{Co}_{3} \mathrm{O}_{4}$ and $\mathrm{Mn}_{3} \mathrm{O}_{4}$ mixed oxides together with places with amorphous structure (no orderly lattice planes) were identified in the HRTEM images with FFT (fast Fourier transform; S9). This may suggest that some of the constituent elements form an amorphous phase. The results are in agreement with Co and Mn chemical states on the catalysts' surface determined by the XPS measurements and the presence of spinel phase found via XRD.

Scanning transmission microscopy using energy-dispersive X-Ray (EDS) analysis was used for 2D atomic resolution chemical mapping of selected samples. Figure 7 shows results of scanning-transmission electron microscopy (STEM) combined with energy-dispersive X-Ray (EDS) analysis for the K(II)600/4 fresh (a) and K(II)/600/4_used (b) samples. It is obvious that independently of the catalyst state, $\mathrm{K}$ is distributed non-homogenously and correlates with the presence of $\mathrm{Mn}$, while the dispersion of cobalt and aluminum is different and more uniform. This indicates that potassium is preferentially bonded to manganese. However, the lack of identified potassium phases in TEM images may suggest that potassium is mainly present in amorphous form (potassium oxide) and/or is non-homogeneously distributed over the surface. This finding correlates with XRD results, where the only potassium containing phase was the $\mathrm{K}-\mathrm{Mn}-\mathrm{O}$ phase (not $\mathrm{K}-\mathrm{Co}-\mathrm{O}$ phase) of the amorphous character, present only in low amounts and thus difficult to detect by XRD.

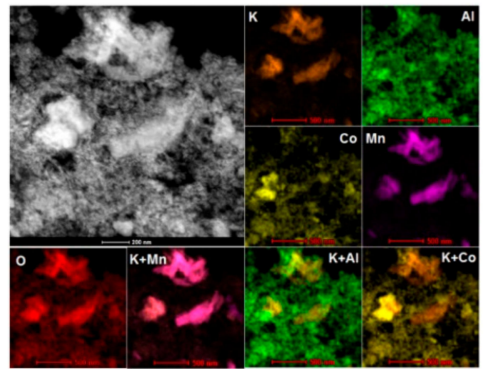

(a)

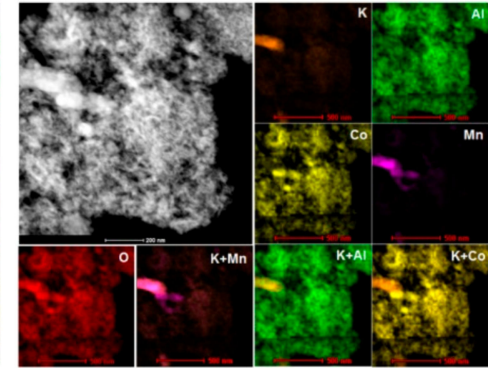

(b)

Figure 7. STEM-energy-dispersive X-Ray (EDS) analysis of K(II)/600/4 fresh (a) and used (b).

No significant difference was observed between the fresh and used sample. 
Particle size measurements of fresh and used samples (Figure 8) showed that after the catalytic reaction, the particles get larger, which is consistent with the results of XRD measurements.

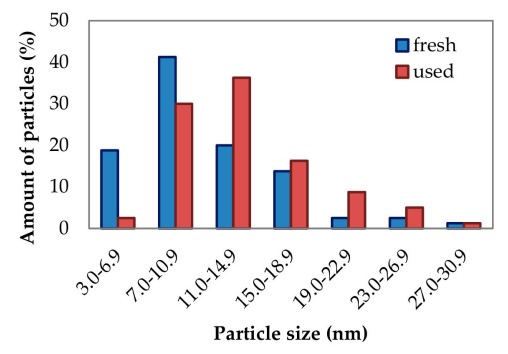

Figure 8. Particle size distribution in fresh and used K(II)/600/4 sample.

\subsubsection{Work Function}

Since it was previously found that catalytic activity correlates with electronic properties of the catalyst surface for oxidation-reduction reactions [50], the influence of potassium doping on work function (WF) was examined for K(IV) series. Potassium, due to its low ionization potential, transfers charge to the catalyst and by formation of the $\mathrm{K}^{\delta+1}-\mathrm{O}_{\text {surf }}{ }^{\delta-1}$ surface dipoles modifies the catalyst work function. According to previous studies [42], the lower the work function of the catalyst, the easier is the oxygen release and thus a correlation of electronic properties, reactivity and reducibility can be expected.

The measurement of WF was done at different conditions (in air or vacuum at room temperature or at $150^{\circ} \mathrm{C}$ ). Since the WF value is very sensitive to the actual surface state, the measurement is strongly influenced by external conditions, so it is more suitable to compare the magnitude of changes in the WF value for the same conditions. In all cases only very small changes of WF were observed for our samples (Table S10). The WF values in vacuum at room temperature are indicative of partial cleaning of the surface. The decrease of WF from 500 to $800{ }^{\circ} \mathrm{C}$ shows a decrease in stability of the weakly adsorbed surface water. Since the K desorption starts before the surface is completely cleaned, it may be inferred that at these temperatures, a surface that is partially covered with water is taking part in the reaction.

Relatively low values of work function indicate the appropriate redox properties of tested catalysts, however a direct correlation of WF values and catalytic activity was not found in contrast to $\mathrm{N}_{2} \mathrm{O}$ decomposition [42]. This could mean that redox properties are important but are not the only factor influencing catalytic activity.

\subsubsection{Species-Resolved Thermal Alkali Desorption}

The stability of potassium on the catalyst surface was studied by species-resolved thermal alkali desorption (SR-TAD). Samples calcined at different temperatures $\left(600-800^{\circ} \mathrm{C}\right)$ containing two different amounts of potassium were tested. The maximum SR-TAD measurement temperatures are different for each sample, since the used experimental set up did not allow fixing the temperature to a constant value. The desorption flux of potassium during heating up to $650{ }^{\circ} \mathrm{C}$ was dominated by atoms in comparison to ions. This is in line with the obtained relatively low work function values, which means that the electron exchange process is easy. During the thermal desorption experiment the K-surface bond is broken and the obtained desorption parameters (flux intensity, activation energy, Arrhenius pre-exponential factor) describe not only the potassium surface stability but also contain information about its surface state, including dispersion [51]. From the temperature-dependent changes of atomic fluxes, it is obvious that potassium desorption from fresh samples can be measured in vacuum already at temperatures of $400{ }^{\circ} \mathrm{C}$ and higher. For that reason, desorption of potassium from the catalyst is possible at the temperatures used for calcination and during NO direct decomposition testing.

In the case of samples with lower amount of K (K(II) samples), non-monotonic curves of the desorption signal dependent on temperature were observed for used samples, while fresh samples 
showed a monotonic increase. The exponential components of the signal were always dominant. This indicates that the potassium promoter predominantly leaves the surface through a single energy barrier. The local maxima, which appeared at lower temperatures, represent loosely-bonded potassium, and indicate its non-homogenous distribution on the catalysts surface [52]. Redistribution of potassium species upon thermal treatment can thus be identified. There are three different $\mathrm{K}$ species in the $\mathrm{K}(\mathrm{II}) / 800 / 4$ used sample, which were not present in the fresh samples. Very low measured desorption flux intensities indicate that only small amounts of these species are present. Formation of different $\mathrm{K}$ species can be connected with a chemical reaction, e.g., formation of nitrates or due to other reason, e.g., formation of $\mathrm{K}_{2} \mathrm{O}$ or clusters of $\mathrm{K}$. First peak could belong to the $\mathrm{K}-\mathrm{K}$ bond e.g., from $\mathrm{K}_{2} \mathrm{O}$, third peak could be $\mathrm{KNO}_{3}$ due to a reaction of $\mathrm{K}$ with $\mathrm{NO}$. The origin of the second peak was unknown. The second peak was missing for K(II)/600/4 used. However, since no deactivation was observed in long term catalytic experiments (Section 2.2. Direct NO decomposition), the new K species were not significant for the catalytic reaction.

For K(IV) samples calcined at 500 and $600^{\circ} \mathrm{C}$ only the third peak of loosely bonded potassium species was present, probably representing $\mathrm{KNO}_{3}$ species (Figure $9 \mathrm{~b}$ ). The samples calcined at higher temperatures were characterized only by a monotonic increase of signal, which means that loosely bonded potassium species were already removed from the surface. However, the intensities were an order of magnitude higher and were shifted to somewhat higher temperatures than for $\mathrm{K}$ (II) samples (Figure 9a). In this case the $\mathrm{KNO}_{3}$ species were probably residuals from the catalyst's synthesis, which did not decompose during calcination below $600^{\circ} \mathrm{C}$ [53].

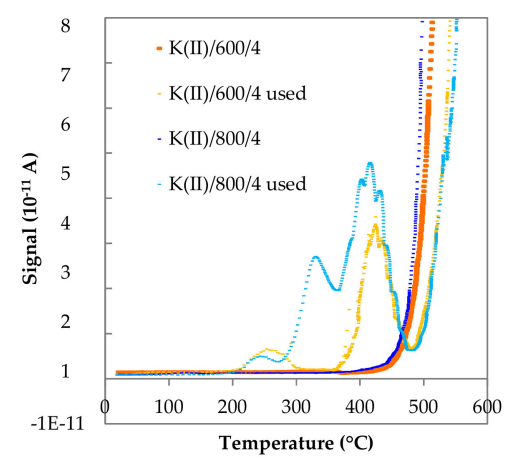

(a)

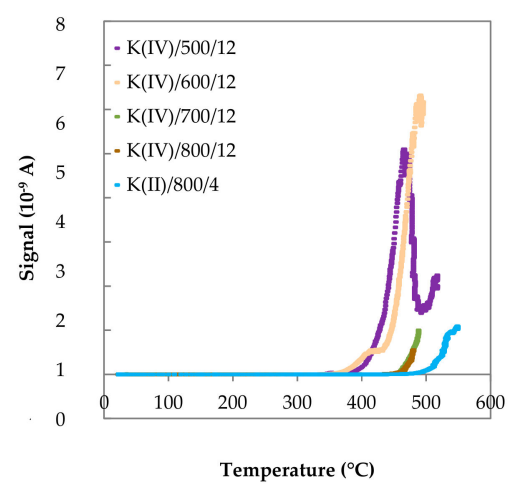

(b)

Figure 9. Atomic K desorption flux as a function of temperature for (a) $K(\mathrm{II}) / 600 / 4$ and $\mathrm{K}(\mathrm{II}) / 800 / 4$ fresh and used samples and (b) used $\mathrm{K}(\mathrm{II}) / 800 / 4$ and $\mathrm{K}(\mathrm{IV}) / y / 12$ samples.

It is interesting that the variance between $\mathrm{K}$ atomic desorption flux as a function of the temperature obtained during heating and during cooling was different for different samples (not shown). Higher desorption flux during heating than during cooling was observed for $\mathrm{K}(\mathrm{IV}) / 500 / 4$ and $\mathrm{K}(\mathrm{IV}) / 600 / 4$; higher desorption flux during cooling was observed for $\mathrm{K}(\mathrm{IV}) / 700 / 4, \mathrm{~K}(\mathrm{IV}) / 800 / 4$ and $\mathrm{K}(\mathrm{II}) / 700 / 4$; almost the same flux during cooling and heating was found for $\mathrm{K}(\mathrm{II}) / 600 / 4$ and crossing of the lines during heating and cooling was visible for $\mathrm{K}(\mathrm{II}) / 800 / 4$ and for used samples. If the signal during heating is higher than during cooling it means that some potassium was already lost during the heating period while when the dependence was the opposite it means that potassium was being accumulated and segregated on the surface during heating. The K(IV)/500/4 and K(IV)/600/4 had the highest amount of potassium and were calcined at the lowest temperatures. For that reason, the observed process of potassium loss was more pronounced for these samples than for samples with lower amounts of potassium or samples already used in the reaction. Based on the different flux profiles obtained during the heating and cooling processes it could be concluded that potassium migration takes place during SR-TAD measurement via three processes: Diffusion inside the bulk, agglomeration on the surface and 
thermal desorption [54]. These processes also probably take place during the stabilization period of the catalytic reaction, which for this type of catalyst requires 10-20 h (see Section 2.2.1 Long term stability).

The desorption activation energies for fresh and used samples determined from the linear parts of the corresponding Arrhenius plots during cooling, assuming first order kinetics, are given in Table 8 . The activation energies of desorption correspond to the strength of a surface chemical bond, which breaks during the desorption process and can be used as a parameter for the evaluation of $\mathrm{K}$ surface stability [52]. The obtained values of $E_{a}$ clearly showed that the activation energy was decreasing with rising calcination temperature and only a very small difference was detected for fresh and used samples (Table 8). Different activation energies revealed changes in the potassium surface state. The attribution of the observed particular activation energies to specific potassium states could be done based on the reference data published in [18], where $E_{a} \sim 2-2.5 \mathrm{eV}$ was found to be characteristic for potassium located on cobalt spinel oxide, while $E_{a} \sim 1.4-1.8$ was attributed to potassium placed on aluminum oxide support. In our case, the decrease of activation energies caused by the increase of catalyst calcination temperature could be connected to potassium migration.

Table 8. Activation energies of $\mathrm{K}$ desorption for selected samples.

\begin{tabular}{cc}
\hline Sample & Activation Energy (eV) \\
\hline $\mathrm{K}(\mathrm{IV}) / 500 / 12$ & 2.7 \\
$\mathrm{~K}(\mathrm{IV}) / 600 / 12$ & 2.6 \\
$\mathrm{~K}(\mathrm{IV}) / 700 / 12$ & 2.3 \\
$\mathrm{~K}(\mathrm{IV}) / 800 / 12$ & 2.2 \\
$\mathrm{~K}(\mathrm{II}) / 600 / 4$ & 2.3 \\
$\mathrm{~K}(\mathrm{II}) / 700 / 4$ & 2.3 \\
$\mathrm{~K}(\mathrm{II}) / 800 / 4$ & 1.9 \\
$\mathrm{~K}(\mathrm{II}) / 600 / 4$ used & 2.1 \\
$\mathrm{~K}(\mathrm{II}) / 800 / 4$ used & 1.8 \\
\hline
\end{tabular}

\subsection{Direct NO Decomposition}

Direct NO decomposition was studied over all samples described in Section 4.1 Catalyst preration. Two types of measurements, given in Section 4.3 Catalyst measurements were performed.

\subsubsection{Long Term Stability}

The effect of calcination temperature, calcination time and potassium amount on the long term stability of K-promoted Co-Mn-Al mixed oxides in direct $\mathrm{NO}$ decomposition was studied. Time dependences of $\mathrm{NO}$ conversion over K-promoted Co-Mn-Al mixed oxides calcined at $500,600,700$ or $800^{\circ} \mathrm{C}$ are depicted in Figure 10a. Time dependences of $\mathrm{NO}$ conversion over K-promoted $\mathrm{Co}-\mathrm{Mn}-\mathrm{Al}$ mixed oxides with different amount of potassium promoter are depicted in Figure 10b. Time dependences of NO conversion over K-promoted Co-Mn-Al mixed oxides calcined at $500{ }^{\circ} \mathrm{C}$ for $4 \mathrm{~h}$ or $12 \mathrm{~h}$ are depicted in Figure 10c. All promoted samples showed similar trends. A stable performance was achieved after a $20 \mathrm{~h}$ period and was maintained until the end of the catalytic test-for $80 \mathrm{~h}$.

During the catalytic tests, the specific surface area decreased and potassium volatilization took place. For that reason, it was supposed that longer calcination time could shorten the stabilization period of NO decomposition. However, the sample calcined for $12 \mathrm{~h}$ showed similar stabilization period (time as well as trend). It means that processes that take place during calcination differ from processes taking place during the stabilization period of NO catalytic decomposition and the latter processes are connected with reaction itself-in other words with the adsorption/desorption processes, the surface coverage by reactants or reaction intermediates or the reaction-induced surface reconstruction, rather than with strictly physical processes. 


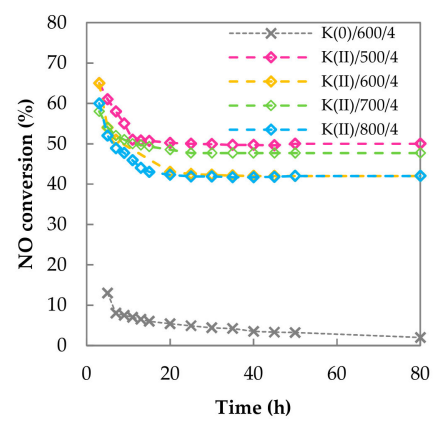

(a)

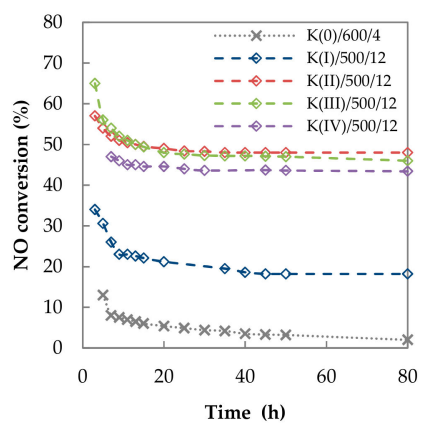

(b)

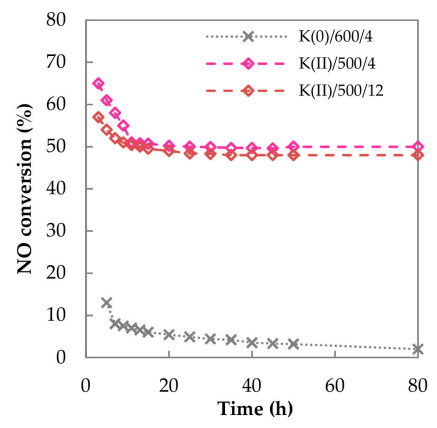

(c)

Figure 10. Long-term stability of (a) K(II)/y/4, (b) $K(x) / 500 / 12$ and (c) $K(\mathrm{II}) / 500 / z$ and $K(0) / 600 / 4$ in direct $\mathrm{NO}$ catalytic decomposition. Conditions: $1000 \mathrm{ppm} \mathrm{NO}$ balanced by $\mathrm{N}_{2}, \mathrm{~T}=650^{\circ} \mathrm{C}$, Gas Hourly Space Velocity $\left(\right.$ GHSV) $=6 \mathrm{lg}^{-1} \mathrm{~h}^{-1}$.

In previous studies it was proposed that the stabilization period is connected with alkali metal vaporization [11], which surely takes place within the time on stream. However, it is interesting that the stabilization process in all cases consists of two parts. The first one is characterized by a fast drop in NO conversion and takes place up to $10 \mathrm{~h}$. Then the conversion drop tends to slow down and lasts for the next $10 \mathrm{~h}$. Since the samples were calcined and some potassium already vaporized during calcination it seems peculiar that the rate of potassium loss followed the fast trend in activity drop (first region) and it seemed that besides alkali vaporization there could be another reason, especially for the first part of the stabilization process of NO catalytic decomposition.

\subsubsection{Catalytic Activity}

The effect of calcination temperature, calcination time and potassium amount on the catalytic activity of K-promoted $\mathrm{Co}-\mathrm{Mn}-\mathrm{Al}$ mixed oxide in direct $\mathrm{NO}$ decomposition was studied in order to define the most suitable conditions at which the most active and stable catalyst can be prepared.

Temperature dependences of NO conversion over K(II) samples calcined for different time periods and at different temperatures are depicted in Figure 11a. The effect of calcination time on catalytic activity was not observed. In Figure 11a, there is moreover a comparison of obtained steady state conversions for $\mathrm{K}(\mathrm{II}) / 500 / 4$ sample when different procedures of catalytic measurement were applied. Surprisingly, similar conversions were obtained in case when the sample was heated as well as in case when the sample was stabilized first at $650{ }^{\circ} \mathrm{C}$ and then was cooled down. For comparison, the NO conversions over the samples from the same set K(II) calcined at different temperatures are also shown in Figure 11a. No significant differences in conversions were found out for these catalysts. Since a change in the $\mathrm{K}-\mathrm{Mn}-\mathrm{O}$ phase of used samples was observed using XRD, it can be concluded that the effect of $\mathrm{K}$ on $\mathrm{NO}$ conversion is independent on the form of the $\mathrm{K}-\mathrm{Mn}-\mathrm{O}$ phase in which potassium was incorporated. Gradual crystallization of the spinel up to $800^{\circ} \mathrm{C}$ (visible from characterizations) did not affect the catalytic activity.

A different situation was observed for the samples containing a lower amount of potassium $(\mathrm{K}(\mathrm{I})$ series, around $0.7 \mathrm{wt} . \% \mathrm{~K}$, Figure $11 \mathrm{~b})$. The activity measured via a heating process was lower than activity measured via a standard cooling process. Moreover, the samples calcined at higher temperatures always exhibited higher activity than the samples calcined at lower temperatures.

The temperature dependence of NO conversion over K-promoted samples containing various amount of $\mathrm{K}$ promoter is shown on Figure 11c. The obtained conversions were different; however, the dependence on $\mathrm{K}$ content was not linear. Deeper insight into the observed phenomenon is given in Section 3. 


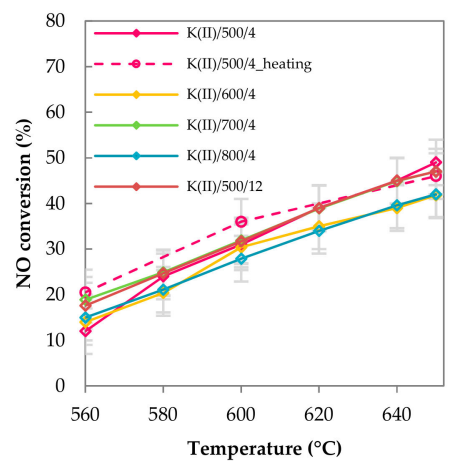

(a)

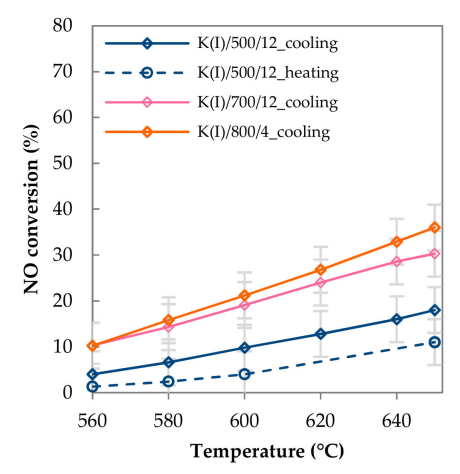

(b)

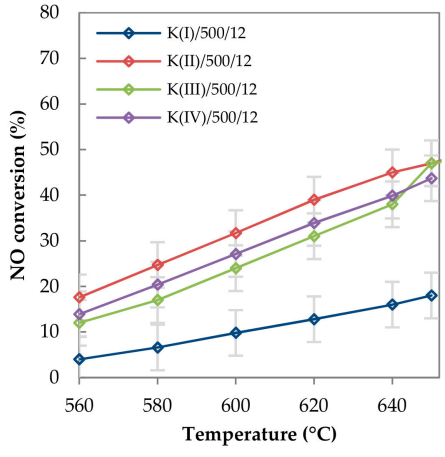

(c)

Figure 11. Temperature dependence of the NO conversion (a) the effect of calcination temperature and time, $\mathrm{K}(\mathrm{II}) / y / z$ catalysts, (b) effect of different procedures of catalytic measurement, $\mathrm{K}(\mathrm{I}) / \mathrm{y} / z$ catalysts and the (c) effect of $\mathrm{K}$ content, $\mathrm{K}(x) / 500 / 12$ catalysts. Conditions: $1000 \mathrm{ppm} \mathrm{NO}$ balanced by $\mathrm{N}_{2}, \mathrm{GHSV}=6 \mathrm{lg}^{-1} \mathrm{~h}^{-1}$.

\section{Discussion}

The aim of the work was to correlate physico-chemical properties of catalyst samples with their catalytic activity and stability and to define appropriate conditions for catalyst preparation and parameters influencing de-NO activity. The determination of appropriate preparation conditions is necessary for further optimization of the catalyst. The defined properties can help avoiding phase transformation processes during the catalytic reaction and allow making presumptions about the alkali metal amount in the calcined sample and determining the appropriate way of catalyst testing to compare samples, which are truly comparable, and not only apparently so (which are actually in different states).

Catalytic activity is often affected by the specific surface area of the catalysts. In our case, no dependence of the catalytic activity on surface area was found out. The samples containing a similar amount of $\mathrm{K}$ had similar activity regardless of the specific surface area determined both for the fresh and the used catalysts (Figure 12a).

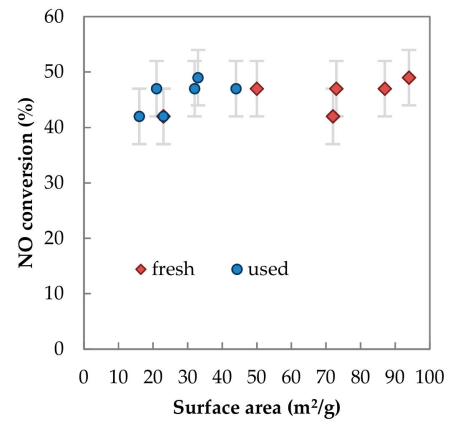

(a)

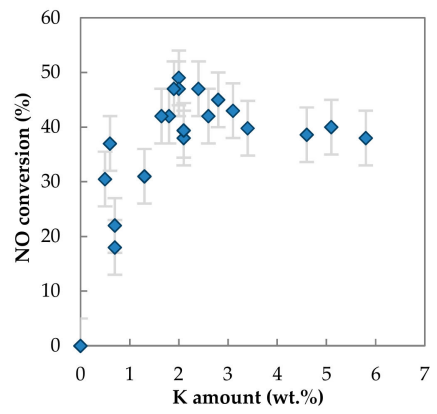

(b)

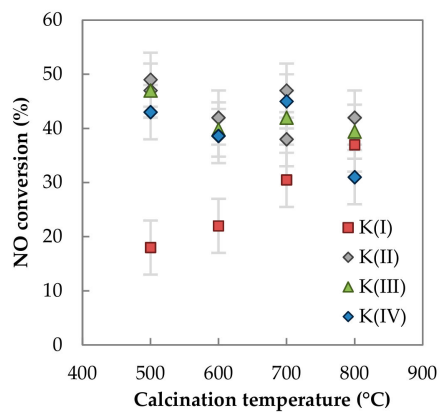

(c)

Figure 12. Dependence of $\mathrm{NO}$ conversion at $650{ }^{\circ} \mathrm{C}$ on (a) the surface area of fresh and used $\mathrm{K}$ promoted Co-Mn-Al mixed oxides containing similar amount of $\mathrm{K}$ ( $2 \mathrm{wt} . \%)$, (b) $\mathrm{K}$ amount and (c) calcination temperature. Conditions: 1000 ppm NO balanced by $\mathrm{N}_{2}, \mathrm{GHSV}=6 \mathrm{lg}^{-1} \mathrm{~h}^{-1}$.

The most evident parameter influencing catalytic activity was the $\mathrm{K}$ amount; however, the effect of the K amount was not so straightforward. While NO conversions over catalysts with $\mathrm{K}$ amount higher than $1 \mathrm{wt} . \%$ had similar values, the sample $\mathrm{K}(\mathrm{I}) / 500 / 12(0.7 \mathrm{wt} . \% \mathrm{~K})$ was significantly less active. For this reason, the dependence of $\mathrm{NO}$ conversion on the $\mathrm{K}$ amount determined via atomic absorption spectrometry (AAS) in fresh samples was depicted for all tested samples regardless of time and temperature used for calcination to elucidate the effect of $\mathrm{K}$ amount on the resulting catalytic 
activity (Figure 12b). It is obvious that NO conversion reached a maximum at around $2-3 \mathrm{wt} . \% \mathrm{~K}$ and with further $\mathrm{K}$ increase, a gradual decrease of $\mathrm{NO}$ was observed. Haneda et al. [22] reported that $\mathrm{NO}$ decomposition takes place at the interface between the alkali metal and mixed oxide and that an optimal K/Co ratio for the reaction exists. Their results showed a similar trend as our results-initial increase of activity with increasing potassium amount followed by a plateau.

A very interesting feature was observed when the conversion of $\mathrm{NO}$ was plotted versus the calcination temperature (Figure 12c). For samples containing more than $1 \mathrm{wt} . \% \mathrm{~K}$, the conversion of $\mathrm{NO}$ did not depend on the calcination temperature up to $700^{\circ} \mathrm{C}$ and a small decrease was observed for samples calcined at $800{ }^{\circ} \mathrm{C}$. This was especially noticeable for the samples containing higher amounts of potassium. The fully opposite trend was observed for samples containing below $1 \mathrm{wt} . \% \mathrm{~K}$-the conversion increased monotonously with rising temperature and samples calcined at $800{ }^{\circ} \mathrm{C}$ reached the same conversion as samples containing a higher amount of potassium. The redistribution of potassium on the catalyst surface due to thermal treatment probably took place and the process was sensitive to potassium amount. This is in accordance with the TAD results, where thermally induced processes of potassium diffusion, migration and desorption were confirmed.

NO conversion is not dependent only on the weight percentage of potassium in the sample, but also depends on the normalized potassium loading expressed as number of potassium atoms per $\mathrm{m}^{2}$ surface area. NO conversion sharply increased at first and after reaching a critical amount of potassium loading $\left(2 \mathrm{~K}\right.$ atoms $\left./ \mathrm{nm}^{2}\right)$, NO conversion slowly decreased with increasing normalized potassium loading (Figure 13).

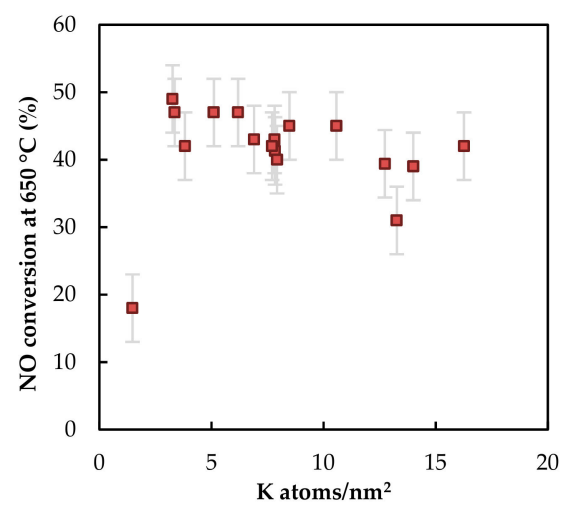

Figure 13. The dependence of $\mathrm{NO}$ conversion at $650^{\circ} \mathrm{C}$ on normalized potassium loading.

The potassium promoter enhances additional catalyst basicity, thus the effect of $\mathrm{K}$ amount on activity should also be related to basic properties of the catalysts. A close correlation of the amount of desorbed $\mathrm{CO}_{2}$ and the $\mathrm{NO}$ decomposition activity on $\mathrm{Co}_{3} \mathrm{O}_{4}$ mixed oxides was published by Haneda [55], where the activity of supported alkaline earth metal oxide catalysts was not related only to the number of basic sites, but also to the strength of basic sites, irrespective of the type of alkaline earth elements. Hong [56] claimed that the addition of alkaline earth components increased the number of basic sites together with their basicity and also correlated NO decomposition activity with the catalyst basicity. Palomares [57] studied multifunctional catalysts/storage materials based on mixed oxides derived from modified layered double hydroxides and concluded that the role of cobalt sites is to oxidize $\mathrm{NO}$ to $\mathrm{NO}_{2}$. The formed $\mathrm{NO}_{2}$ was quickly adsorbed on the basic sites of the catalyst to form nitrites and nitrates on the catalyst surface [57]; the addition of sodium increased the alkalinity of the system resulting in a higher storage capacity of $\mathrm{NO}_{\mathrm{x}}$ as nitrates. For that reason, alkali metals are often present in $\mathrm{NO}_{x}$ storage/reduction catalysts.

In Figure $6 \mathrm{c}$ the results of TPD $\mathrm{CO}_{2}$ are given also for the samples without potassium, which are not active in NO decomposition ("zero point"). It is evident that when the area of peaks above 250 and $300^{\circ} \mathrm{C}$ were taken into account, the "zero point" suited the trend, while in other cases (below and above these temperatures) the zero point did not match the shown dependences. Therefore, it was 
assumed that basic sites having temperature maxima between 250 and $400{ }^{\circ} \mathrm{C}$ could play an important role in NO catalytic decomposition. Simultaneously, the most active samples were those with basic sites characterized by the maximum in TPD spectra at about $430{ }^{\circ} \mathrm{C}$ (Figure 14a). The type of sites seems to be more important than their amount if a minimal critical amount of potassium (and thus basic sites) was ensured. A minimal critical amount of potassium, $>1 \mathrm{wt} . \% \mathrm{~K}$, could be estimated from Figure $14 \mathrm{~b}$ where NO conversion remained constant after a certain amount of basic sites.

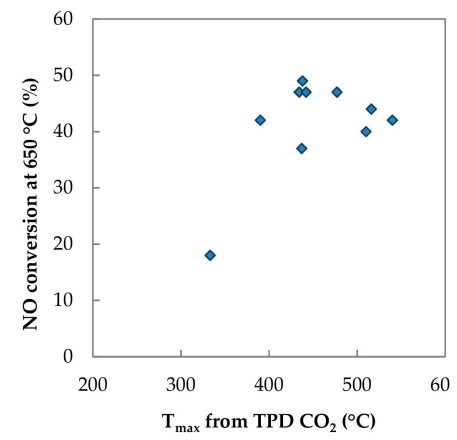

(a)

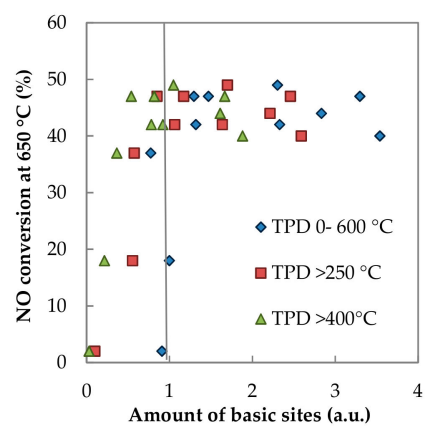

(b)

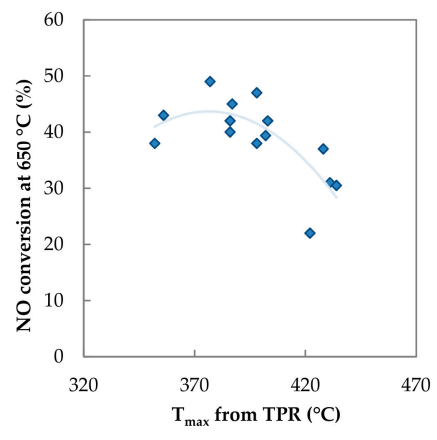

(c)

Figure 14. (a) The dependence of NO conversion on the temperature maximum of the main peak acquired from $\mathrm{TPD} \mathrm{CO}_{2}$ results, (b) the dependence of $\mathrm{NO}$ conversion on the temperature maximum of the main peak acquired from TPR- $\mathrm{H}_{2}$ and (c) the dependence of the NO conversion on the amount of basic sites.

The catalyst's activity was also connected with its reducibility-the optimal temperature $\left(370-400{ }^{\circ} \mathrm{C}\right)$ of the main reduction peak was necessary for achieving the best catalytic performance (Figure 14c). It means that the optimal strength of the transition metal-oxygen bond is necessary for achieving a high activity for NO decomposition. Since the temperature of the maxima of the main peak shifted to lower temperatures with increasing K amount (Figure S6 in Supplementary Materials), the optimum K amount ensuring desired reducibility is essential. Nevertheless, the reducibility is not the only factor influencing catalyst activity, since the work function did not correlate directly with catalyst activity.

In general, NO direct catalytic decomposition proceeds via the following steps [58]: NO adsorption, reactions of adsorbed $\mathrm{NO}$ on the surface leading to formation of $\mathrm{NO}_{\mathrm{x}}$ species, decomposition of surface $\mathrm{NO}_{x}$ species and desorption of $\mathrm{N}_{2}$ and $\mathrm{O}_{2}$. The surface ionic $\mathrm{NO}_{\mathrm{x}}$ species are commonly mentioned reaction intermediates of $\mathrm{NO}$ decomposition. Haneda [22,58] proposed that over alkali metal doped $\mathrm{Co}_{3} \mathrm{O}_{4}$ catalysts, $\mathrm{NO}_{2}{ }^{-}$species probably react with another $\mathrm{NO}$ adspecies resulting in the formation of $\mathrm{N}_{2} \mathrm{O}_{x}$ intermediates, which decompose very fast into gaseous $\mathrm{N}_{2}$ and adsorbed oxygen species. In the literature, it was most often considered that oxygen desorption is the rate determining step; however, some other steps like the attack of second $\mathrm{NO}$ molecule on the oxygen vacancy, $\mathrm{NO}_{2}$ formation, $\mathrm{N}_{2} \mathrm{O}$ formation and decomposition were also considered by different authors [59,60]. Anyway, the suggestion that the formation of $\mathrm{N}_{2}$ is directly caused from the collision of two activated nitrogen atoms and that formation of $\mathrm{O}_{2}$ is combined by the two adsorbed oxygen atoms is valid across a lot of different studies [60].

The active catalytic material has to ensure different functionalities according to the NO decomposition mechanism. The role of transition metals is to oxidize $\mathrm{NO}$ to $\mathrm{NO}_{2}$ [61], while the formed $\mathrm{NO}_{2}$ is adsorbed on the basic sites of the catalyst to form nitrites and nitrates. Here the charge neutrality for the formation of $\mathrm{NO}_{2}{ }^{-}$or $\mathrm{NO}_{3}{ }^{-}$species can be retained by oxidation of $\mathrm{Me}^{\mathrm{x}+}$ cation to form $\mathrm{Me}^{\mathrm{x}+1}$, where Me is Co or $\mathrm{Mn}$. In order to close the catalytic cycle via oxygen desorption, the presence of transition metal with appropriate redox properties is again important. 
Our results show that potassium presence in Co-Mn-Al mixed oxide influences not only basic properties connected to $\mathrm{NO}$ adsorption and $\mathrm{NO}_{\mathrm{x}}$ storage, but also redox properties, which are necessary for the activation of $\mathrm{NO}$ molecule and oxygen desorption.

\section{Materials and Methods}

\subsection{Catalyst Preparation}

The Co-Mn-Al layered double hydroxide precursor with the Co:Mn:Al molar ratio of 4:1:1 was prepared by coprecipitation of corresponding nitrates in an alkaline $\mathrm{Na}_{2} \mathrm{CO}_{3} / \mathrm{NaOH}$ solution . The precipitate was filtered off, washed with water, dried and calcined at 500, 600, 670, 700 or $800{ }^{\circ} \mathrm{C}$ for 4 or $12 \mathrm{~h}$ in static air.

Samples modified with potassium promoter were prepared by the bulk promotion method. The washed precipitate of $\mathrm{Co}-\mathrm{Mn}$-Al layered double hydroxide precursor was dispersed in an aqueous $\mathrm{KNO}_{3}$ solution of different concentrations and the dried filtration cake was calcined in air at $500-800^{\circ} \mathrm{C}$ for 4 or $12 \mathrm{~h}$ and denoted as $\mathrm{K}(x) / y / z$, where $x$ means modification by different $\mathrm{K}$ amounts (the same sample group means that sample was modified by the same amount of $\mathrm{K}$ before calcination), $y$ means calcination temperature $\left({ }^{\circ} \mathrm{C}\right)$ and $z$ means calcination time $(\mathrm{h})$.

The catalytic activity was measured for 24 samples (K(II)/500/4, K(II)/600/4, K(II)/700/4, K(II)/800/4, $\mathrm{K}(\mathrm{I}) / 500 / 12, \mathrm{~K}(\mathrm{II}) / 500 / 12, \mathrm{~K}(\mathrm{III}) / 500 / 12, \mathrm{~K}(\mathrm{IV}) / 500 / 12, \mathrm{~K}(\mathrm{I}) / 600 / 4, \mathrm{~K}(\mathrm{I}) / 800 / 4, \mathrm{~K}(\mathrm{II}) / 700 / 12, \mathrm{~K}(\mathrm{III}) / 700 / 12$, $\mathrm{K}(\mathrm{IV}) / 700 / 12, \mathrm{~K}(\mathrm{III}) / 800 / 12, \mathrm{~K}(\mathrm{IV}) / 800 / 12, \mathrm{~K}(\mathrm{III}) / 600 / 12, \mathrm{~K}(\mathrm{IV}) / 600 / 12, \mathrm{~K}(\mathrm{I}) / 700 / 12, \mathrm{~K}(0) / 800 / 4, \mathrm{~K}(0) / 700 / 4$, $\mathrm{K}(0) / 600 / 4, \mathrm{~K}(0) / 670 / 4, \mathrm{~K}(\mathrm{~V}) / 700 / 4$ and $\mathrm{K}(\mathrm{V}) / 800 / 4)$, the characterization was done only for selected samples.

\subsection{Catalyst Characterization}

Chemical composition of the laboratory prepared catalysts was determined by atomic absorption spectrometry (AAS) or inductive coupled plasma (ICP) spectrometry. $\mathrm{K}, \mathrm{Co}, \mathrm{Mn}$ and $\mathrm{Al}$ were analyzed using AAS on a ContrAA 700 atomic absorption spectrometer (Analytik Jena AG, Jena, Germany) using flame atomization technique. Approximately $50 \mathrm{mg}$ of the sample in powder form was weighed in teflon vessels of a SK-15 rotor of a microwave digestion system (Milestone Ethos Up, Sorisole, Italy). Nitric $(2 \mathrm{~mL})$ and hydrochloric $(6 \mathrm{~mL})$ acids were added (both p.a. (proanalysis) purity, Penta chemicals, Prague, Czech Republic) to form aqua regia and vessels were closed. The digestion program has three steps with power output set to maximum (1800 W, not applied full time): (1) 10-min ramp from laboratory temperature to $220^{\circ} \mathrm{C}$; (2) $15 \mathrm{~min}$ hold at $220^{\circ} \mathrm{C}$ and (3) $30 \mathrm{~min}$ cooling. After cooling, vessels were opened, the sample solutions transferred into $50 \mathrm{~mL}$ volumetric flasks, washings were added to the sample and the flasks were filled up to $50 \mathrm{~mL}$ with deionized water. With each batch of digestions one blank digestion was performed. For each element different wavelength and flame type was applied: $766.49 \mathrm{~nm}$ and $\mathrm{C}_{2} \mathrm{H}_{2} /$ Air for $\mathrm{K}, 240.73 \mathrm{~nm}$ and $\mathrm{C}_{2} \mathrm{H}_{2} /$ Air for $\mathrm{Co}, 279.48 \mathrm{~nm}$ and $\mathrm{C}_{2} \mathrm{H}_{2} / \mathrm{Air}$ for $\mathrm{Mn}$ and $396.15 \mathrm{~nm}$ and $\mathrm{C}_{2} \mathrm{H}_{2} / \mathrm{N}_{2} \mathrm{O}$ for $\mathrm{Al}$.

For ICP measurements the Agilent 725 ICP OES Spectrometer (Agilent Technologies, Mulgrave, Australia) was used. $0.1 \mathrm{~g}$ of sample in powder form was dissolved in aqua regia and transferred to a $250 \mathrm{~mL}$ volumetric flask. Metals (K, Co, Mn, $\mathrm{Al}$ ) were analyzed on an emission spectrometer with inductively coupled plasma using the calibration curve method with standard solutions by the Merck company.

Phase composition and microstructural properties were determined using the $\mathrm{X}$-ray powder diffraction (XRD) technique. XRD patterns were obtained using Rigaku SmartLab powder diffractometer (Rigaku, Tokyo, Japan) with a D/teX Ultra 250detector. The source of X-ray irradiation was Co tube $(\mathrm{CoK} \alpha, \lambda 1=0.178892 \mathrm{~nm}, \lambda 2=0.179278 \mathrm{~nm})$ operated at $40 \mathrm{kV}$ and $40 \mathrm{~mA}$. Incident and diffracted beam optics were equipped with $5^{\circ}$ Soller slits; incident slits were set up to irradiate a $10 \times 10 \mathrm{~mm}$ area of the sample (automatic divergence slits) constantly. Slits on the diffracted beam were set up to a fixed value of 8 and $14 \mathrm{~mm}$. The powder samples were gently grinded using agate mortar before analysis and pressed using microscope glass in a rotational sample holder and measured in the 
reflection mode (Bragg-Brentano geometry). The samples rotated (30 rpm) during the measurement to eliminate the preferred orientation effect. The XRD patterns were collected in a $2 \theta$ range $5-90^{\circ}$ with a step size of $0.01^{\circ}$ and speed of $0.5^{\circ} \mathrm{min}^{-1}$. Measured XRD patterns were evaluated using the PDXL 2 software (version 2.4.2.0) and compared with the PDF-2database, release 2015.XRD patterns were analyzed using the LeBail method (software PDXL2) to refine lattice parameters of the spinel like phase. Background of the patterns was determined using B-Spline function, peak shapes were modeled with a pseudo-Voigt function accounting for a peak asymmetry due to axial divergence. Mean coherent domain corresponding to spinel crystallite size was calculated using the Scherrer's formula with correction to the instrumental broadening. Mean coherent domain corresponding to spinel crystallite size was calculated using Scherrer's formula from spinel hkl reflections (220), (211), (400), (511) and (440). The calculated value was corrected to the instrumental broadening using silicon standard (NIST SRM 640d).

Superficial elemental analyses were performed by XPS (X-ray Photoelectron Spectrometer ESCA 3400, Kratos, Manchester, England; base pressure better than $5 \cdot 10^{-7} \mathrm{~Pa}$ ), using a polychromatic $\mathrm{Mg}$

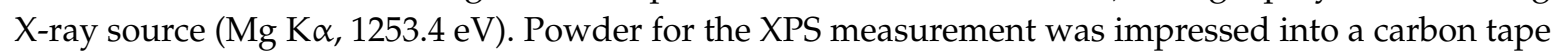
(double sided adhesive carbon tape, SPI Supplies). The carbon tape was completely covered by the powder; therefore, only a very low signal originated from the carbon tape itself. Composition of the powder was determined without any annealing $\left(\mathrm{Ar}^{+}\right.$ion gun, $\left.0.5 \mathrm{kV}, 10 \mathrm{~mA}, 90 \mathrm{~s}\right)$. For all spectra, the Shirley background was subtracted and elemental compositions of layers were calculated from the areas of $\mathrm{Co} 2 \mathrm{p}, \mathrm{Mn} 2 \mathrm{p}, \mathrm{Al} 2 \mathrm{p}, \mathrm{O} 1 \mathrm{~s}, \mathrm{C} 1 \mathrm{~s}, \mathrm{Na}$ and $\mathrm{K} 2 \mathrm{p}$. The carbon correction was done by setting the position of $\mathrm{C} 1 \mathrm{~s}$ peak to $284.8 \mathrm{eV}$.

The electron microscope Tecnai G2 20 X-TWIN FEI Company, equipped with: A LaB6 gun, HAADF detector and an EDS spectrometer (energy dispersive X-Ray spectroscopy) (FEI company, Eindhoven, The Netherlands) was used to display the prepared catalysts. Microscopic studies of the catalysts were carried out at an accelerating voltage of the electron beam equal to $200 \mathrm{kV}$. The elements mapping was carried out in the STEM mode by collecting point by point the EDS spectrum of each of the corresponding pixels in the map. The collected maps were presented in the form of a matrix of pixels with the color mapped significant element and the intensity corresponding to the percentage of the element. Before STEM measurement, the catalysts were grinded in an agate mortar to a fine powder. The resulting powders were mixed with $99.8 \%$ ethanol $(\mathrm{POCH})$ to form a slurry, which was subsequently inserted into an ultrasonic homogenizer for $20 \mathrm{~s}$. Then, the slurry containing the catalyst was pipetted and supported on a 200 mesh copper grid covered with Lacey Formvar and stabilized with carbon (Ted Pella Company, Redding, USA) and left on the filter paper until the ethanol has evaporated. Subsequently, the samples deposited on the grid were inserted into a holder and placed into the electron microscope.

$\mathrm{N}_{2}$ physisorption at $-196^{\circ} \mathrm{C}$ was performed on AutoChem II (Micromeritics, Atlanta, GA, USA) and the one point BET method was used for specific surface area evaluation. Before analysis, each sample was degassed for one hour at $450{ }^{\circ} \mathrm{C}$ in He flow of $50 \mathrm{~mL} / \mathrm{min}$. After degassing, the mixture of $30 \mathrm{~mol} \% \mathrm{~N}_{2}$ and $70 \mathrm{~mol}$. \% He was applied to the sample that was immersed in liquid nitrogen. The amount of $\mathrm{N}_{2}$ adsorbed at liquid nitrogen temperature was used to calculate the surface area.

Nitrogen physisorption measurements were also carried out on the 3Flex adsorption apparatus (Micromeritics, Atlanta, GA, USA). The nitrogen adsorption-desorption isotherms were measured at $77 \mathrm{~K}$ after $120 \mathrm{~h}$ degassing of the samples at $350^{\circ} \mathrm{C}$. The specific surface area, $S_{\mathrm{BET}}$, was calculated according to the classical Brunauer-Emmett-Teller (BET) theory for the $p / p_{0}$ range $=0.05-0.30$. Pore-size distribution was calculated from the adsorption branch of the nitrogen adsorption-desorption isotherm using the Barret-Joyner-Halenda (BJH) method, the empirical Broekhoff-De Boer standard isotherm and assuming cylindrical pore geometry.

The temperature programmed reduction by hydrogen $\left(\mathrm{TPR}-\mathrm{H}_{2}\right)$ was carried out on Autochem II 2920 (Micromeritics, Atlanta, GA, USA) with a sample amount $0.07 \mathrm{~g}$. Prior to the TPR experiments, the samples were outgassed in the flow of pure argon $(50 \mathrm{~mL} / \mathrm{min})$ at $600{ }^{\circ} \mathrm{C}$ for $60 \mathrm{~min}$, cooled down 
to $30{ }^{\circ} \mathrm{C}$ in the same atmosphere and afterwards the TPR runs were performed in the flow of $10 \mathrm{~mol} . \%$ $\mathrm{H}_{2} / \mathrm{Ar}(50 \mathrm{~mL} / \mathrm{min})$ with a heating rate $20^{\circ} \mathrm{C} / \mathrm{min}$ in the temperature range of $30-600{ }^{\circ} \mathrm{C}$. After reaching $600^{\circ} \mathrm{C}$, the temperature was kept constant for $20 \mathrm{~min}$. A cold trap $\left(-78^{\circ} \mathrm{C}\right)$ was applied to eliminate the water evolved during experiments.

Temperature programmed desorption of $\mathrm{CO}_{2}\left(\mathrm{TPD}-\mathrm{CO}_{2}\right)$ was carried out on Autochem II 2920 (Micromeritics, Atlanta, GA, USA) connected on-line to a mass spectrometer (Prevac). A sample amount of $0.07 \mathrm{~g}$ was used. The procedure involved the activation of the samples in flowing $\mathrm{He}$ $(50 \mathrm{~mL} / \mathrm{min})$ at $600{ }^{\circ} \mathrm{C}(1 \mathrm{~h})$, cooling to $28^{\circ} \mathrm{C}$ (adsorption temperature), and adsorbing $\mathrm{CO}_{2}$ from a stream of $\mathrm{He}-\mathrm{CO}_{2}(50 \% ; 1 \mathrm{~h})$. The flow rate of the gas mixture was $50 \mathrm{~mL} / \mathrm{min}$. To remove physically adsorbed $\mathrm{CO}_{2}$, the samples were purified for $110 \mathrm{~min}$ in the helium stream $(50 \mathrm{~mL} / \mathrm{min})$ at $28^{\circ} \mathrm{C}$ and subsequent desorption (TPD- $\left.\mathrm{CO}_{2}\right)$ was carried out in the temperature range of $28-600^{\circ} \mathrm{C}\left(20^{\circ} \mathrm{C} / \mathrm{min}\right)$ under helium flow $(50 \mathrm{~mL} / \mathrm{min})$.

Thermal stability of alkali metal promoters was investigated by the species resolved thermal alkali desorption (SR-TAD) method. The experiments were carried out in a vacuum apparatus with a background pressure of $10^{-7} \mathrm{kPa}$. The samples in the form of wafers $(10 \mathrm{~mm}$ diameter, $100 \mathrm{mg}$ weight) were heated up from room temperature to $650{ }^{\circ} \mathrm{C}$ in a stepwise mode at the rate of $5{ }^{\circ} \mathrm{C} \mathrm{min}-1$. The desorption flux of potassium atoms was determined by means of a surface ionization detector, whereas the flux of ions was determined with an ion collector. During the measurements, the samples were biased with a positive potential $(+10$ and $+100 \mathrm{~V}$ for atoms and ions, respectively) to quench the thermal emission of electrons and additionally, in the case of ions, to accelerate them towards the collector. In this way, the possibility of reneutralization of ions by thermal electrons outside of the surface is effectively eliminated. In all measurements, the resulting positive current was directly measured with a Keithley 6512 digital electrometer (Cleveland, USA).

The redox properties of the catalysts were investigated by work function measurement using the Kelvin Probe (KP) method. The experiments were carried out in a vacuum apparatus with a background pressure of $10^{-7} \mathrm{kPa}$. The samples in the form of wafers (10 mm diameter, $100 \mathrm{mg}$ weight) were measured first at room temperature and pressure, then at room temperature and vacuum, then heated to $400{ }^{\circ} \mathrm{C}$ at the rate of $20^{\circ} \mathrm{C} \mathrm{min}-1$ and then after $30 \mathrm{~min}$ left to cool down to $150{ }^{\circ} \mathrm{C}$ and measured at this temperature, and after cooling down to room temperature measured again. For the measurements a KP 6500 (McAllister Technical Services, Coeur d'Alene, Idaho, USA) reference electrode with a work function $\phi_{\text {ref }}=4.1 \mathrm{eV}$ was used. The work function of a sample was evaluated based on 20 independent values of contact potential difference between the sample and the reference electrode.

Characterization of the catalysts was done for fresh samples but in some cases also for samples used in catalytic tests, since some changes of the physico-chemical properties induced by the NO decomposition reaction as well as resulting from long term high temperature exposition were expected.

\subsection{Catalytic Measurements}

Catalytic NO decomposition was performed in an integral fixed bed stainless steel reactor of $6 \mathrm{~mm}$ internal diameter. The catalyst bed contained $0.5 \mathrm{~g}$ of the sample with a particle size of $0.16-0.315 \mathrm{~mm}$. Total flow was kept at $49 \mathrm{~mL} \mathrm{m^{-1 }}\left(20^{\circ} \mathrm{C}\right.$, atmospheric pressure). An infrared spectrometer Ultramat 6 (Siemens, Karlsruhe, Germany ) was used for $\mathrm{NO}$ online analysis. The low-temperature $\mathrm{NO}_{2} / \mathrm{NO}$ converter (TESO Ltd., Prague, Czech Republic) was connected at the bypassed line before the NO analyzer and the gas for analysis was periodically switched through the convertor in order to analyze the sum of $\mathrm{NO}_{\mathrm{x}}$ and thus control the amount of $\mathrm{NO}_{2}$. The presence of $\mathrm{N}_{2} \mathrm{O}$ species was controlled on an FTIR spectrometer Antaris IGS (Nicolet, Prague, Czech Republic). The measurement error of NO conversion was determined by repeated measurements as $\pm 5 \%$ (absolute error).

The typical procedure was as follows: After catalyst activation (heating in $\mathrm{N}_{2}$, then $1 \mathrm{~h}$ in $\mathrm{N}_{2}$ at $650{ }^{\circ} \mathrm{C}$ ), the NO catalytic decomposition at $650^{\circ} \mathrm{C}$ was measured for $50 \mathrm{~h}$ to reach steady state. After this period, when stable performance was achieved, the temperature dependence of NO conversion was determined with cooling rate of $5^{\circ} \mathrm{C} \mathrm{min}^{-1}$ and the catalysts activity was measured for $3 \mathrm{~h}$ at each 
temperature $\left(640{ }^{\circ} \mathrm{C}, 620^{\circ} \mathrm{C}, 600^{\circ} \mathrm{C}, 580^{\circ} \mathrm{C}\right.$ and $\left.560{ }^{\circ} \mathrm{C}\right)$. After the conversion curve measurement, the reactor was heated back to $650^{\circ} \mathrm{C}$ and catalysts stability after $80 \mathrm{~h}$ was evaluated. In case the performance was stable, the catalyst was heated to $700{ }^{\circ} \mathrm{C}$ and steady state $\mathrm{NO}$ conversion at $700{ }^{\circ} \mathrm{C}$ was measured. In order to elucidate phases evolution in the studied $\mathrm{K} / \mathrm{Co}-\mathrm{Mn}-\mathrm{Al}$ system and to choose the best calcination temperature related to catalytic activity as well as to catalyst stability, the calcination temperatures of 500 and $600{ }^{\circ} \mathrm{C}$ were also applied.

For two selected samples (K(II)/500/4, K(II)/600/4), the catalytic activity measurement was performed not only by the procedure given above but it was also adjusted as follows: After catalyst activation (heating in $\mathrm{N}_{2}$, then $1 \mathrm{~h}$ in $\mathrm{N}_{2}$ at $650{ }^{\circ} \mathrm{C}$ ), the $\mathrm{NO}$ catalytic decomposition at $500{ }^{\circ} \mathrm{C}$ was measured until reaching stable performance. After that the temperature was raised to $560^{\circ} \mathrm{C}$ and the measurement was performed until reaching stable performance. The same step was repeated for 600 and $650{ }^{\circ} \mathrm{C}$. For the rest of the samples calcined at 500 or $600{ }^{\circ} \mathrm{C}$ measured by the described typical procedure, it is necessary to keep in mind that they were actually re-calcined to $650^{\circ} \mathrm{C}$ during the activation and measurement of $\mathrm{NO}$ catalytic decomposition at $650{ }^{\circ} \mathrm{C}$.

\section{Conclusions}

From the results obtained in this work, we can conclude that Co-Mn-Al oxides promoted by potassium are active in direct NO decomposition. The activity is given by the diversity of active surface sites. The presence of potassium improves catalysts' basicity and reducibility, both factors influencing the catalytic deNO activity.

The calcination temperature affects the specific surface area, pore size, reducibility, basicity, the alkali metal volatilization process, the amount of residual potassium (after volatilization) and phase composition of the catalyst. XRD measurements showed that the presence of alkali metal influenced the position of atoms in the spinel unit cell as well as the shape and size of the unit cell. The calcination time affects the specific surface area, amount of residual potassium and catalyst crystallinity. The type of the potassium-containing phase is temperature dependent; however, if a sufficient amount of potassium promoter is present at the surface, the surface state of $\mathrm{K}$ does not influence NO conversion. The best catalytic performance was achieved for catalysts containing more than $1 \mathrm{wt} . \% \mathrm{of}$ K. The calcination temperatures of 700 and $800{ }^{\circ} \mathrm{C}$ were found to be the best for direct $\mathrm{NO}$ decomposition regarding achieved activity as well as potassium promoter stability.

The schematic diagram of the catalyst changes taking place during preparation and NO catalytic decomposition is given in Figure 15.

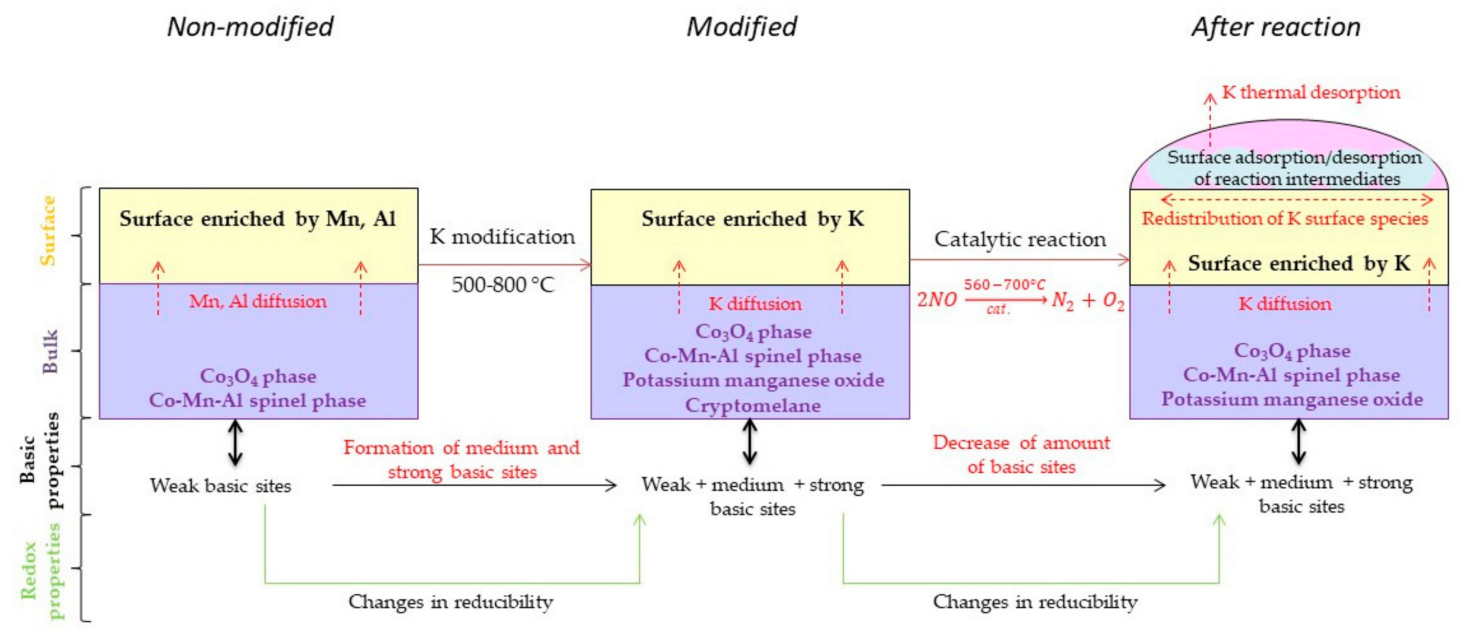

Figure 15. The schematic diagram of the potassium modified $\mathrm{Co}-\mathrm{Mn}-\mathrm{Al}$ mixed oxide catalyst changes during preparation and NO catalytic decomposition. 
The resulting potassium phases differ according to the applied potassium amount and the temperature used for calcination, which are subject to subsequent changes (diffusion, migration, redistribution, volatilization) during the catalytic process. However, if the minimal critical amount of potassium is reached $(>1 \mathrm{wt} . \% \mathrm{~K})$, a stable and active catalyst is obtained.

Supplementary Materials: The following are available online at http://www.mdpi.com/2073-4344/9/7/593/s1, Figure S1: XRD results for samples K(II)/y/4., Figure S2: XRD results for samples K(x)/600/z., Figure S3: XRD results for samples $\mathrm{K}(x) / 800 / z$, Figure S4: XPS results., Figure S5: $\mathrm{TPR}_{2}$-effect of potassium amount., Figure S6: $\mathrm{T}_{\max }$ (from TPR $\mathrm{H}_{2}$ ) dependence on $\mathrm{K}$ amount, Figure S7: TPR $\mathrm{H}_{2}$ - effect of calcination temperature for samples $\mathrm{K}(\mathrm{II}) / y / 4$., Figure S8: TPR $\mathrm{H}_{2}$ - effect of calcination temperature for samples K(I)/y/z., Table S9: Work function of selected samples.

Author Contributions: Conceptualization, K.P. and T.B.; methodology, K.P.; validation, T.B., L.O., A.K. and K.J.; investigation, T.B., K.P., K.K., A.K., W.K., T.K., D.F., M.K., P.S. and J.B.; data curation, T.B., D.F., K.P., K.K., A.K., W.K., P.S. and T.K.; writing-original draft preparation, K.P..; writing—review and editing, K.P. and T.B.; supervision, L.O.; project administration, K.P., L.O. and K.J.

Funding: This research was funded by ERDF “Institute of Environmental Technology-Excellent Research" (No. CZ.02.1.01/0.0/0.0/16_019/0000853), by the Ministry of Education, Youth and Sports of the Czech Republic- project No. LM2012039 and LM2015039, by Czech Science Foundation-project No. 18-19519S and by VSB-TU internal student project No. SP2019-91.

Acknowledgments: The authors are grateful to Lenka Matějová for nitrogen physisorption and Alexandr Martaus for XRD analyses.

Conflicts of Interest: The authors declare no conflict of interest. The funders had no role in the design of the study; in the collection, analyses, or interpretation of data; in the writing of the manuscript, or in the decision to publish the results.

\section{References}

1. Falsig, H.; Bligaard, T.; Rass-Hansen, J.; Kustov, A.; Christensen, C.; Nørskov, J. Trends in catalytic NO decomposition over transition metal surfaces. Top. Catal. 2007, 45, 117-120. [CrossRef]

2. Garin, F. Mechanism of $\mathrm{NO}_{x}$ decomposition. Appl. Catal. A 2001, 222, 183-219. [CrossRef]

3. Brown, W.A.; King, D.A. NO Chemisorption and Reactions on Metal Surfaces: A New Perspective. J. Phys. Chem. B 2000, 104, 2578-2595. [CrossRef]

4. Inderwildi, O.R.; Jenkins, S.J.; King, D.A. When adding an unreactive metal enhances catalytic activity: $\mathrm{NO}_{\mathrm{x}}$ decomposition over silver-rhodium bimetallic surfaces. Surf. Sci. 2007, 601, L103-L108. [CrossRef]

5. Kumar, A.; Medhekar, V.; Harold, M.P.; Balakotaiah, V. NO decomposition and reduction on $\mathrm{Pt} / \mathrm{Al}_{2} \mathrm{O}_{3}$ powder and monolith catalysts using the TAP reactor. Appl. Catal. B 2009, 90, 642-651. [CrossRef]

6. Modén, B.; Da Costa, P.; Fonfé, B.; Lee, D.K.; Iglesia, E. Kinetics and Mechanism of Steady-State Catalytic NO Decomposition Reactions on Cu-ZSM5. J. Catal. 2002, 209, 75-86. [CrossRef]

7. Ganemi, B.; Björnbom, E.; Paul, J. Conversion and in situ FTIR studies of direct NO decomposition over Cu-ZSM5. Appl. Catal. B 1998, 17, 293-311. [CrossRef]

8. Shi, Y.; Pan, H.; Li, Z.; Zhang, Y.; Li, W. Low-temperature decomposition of $\mathrm{NO}_{x}$ over Fe-Mn/H-beta catalysts in the presence of oxygen. Catal. Commun. 2008, 9, 1356-1359. [CrossRef]

9. Haneda, M.; Kintaichi, Y.; Hamada, H. Surface reactivity of prereduced rare earth oxides with nitric oxide: New approach for NO decomposition. Phys. Chem. Chem. Phys. 2002, 4, 3146-3151. [CrossRef]

10. Hamada, H.; Kintaichi, Y.; Sasaki, M.; Ito, T. Silver-promoted cobalt oxide catalysts for direct decomposition of nitrogen oxides. Chem. Lett. 1990, 19, 1069-1070. [CrossRef]

11. Pacultová, K.; Draštíková, V.; Chromčáková, Ž.; Bílková, T.; Kutláková, K.M.; Kotarba, A.; Obalová, L. On the stability of alkali metal promoters in Co mixed oxides during direct NO catalytic decomposition. Mol. Catal. 2017, 428, 33-40. [CrossRef]

12. Haneda, M.; Kintaichi, Y.; Bion, N.; Hamada, H. Alkali metal-doped cobalt oxide catalysts for NO decomposition. Appl. Catal. B Environ. 2003, 46, 473-482. [CrossRef]

13. Cheng, J.; Wang, X.; Ma, C.; Hao, Z. Novel Co-Mg-Al-Ti-O catalyst derived from hydrotalcite-like compound for NO storage/decomposition. J. Environ. Sci. 2012, 24, 488-493. [CrossRef]

14. Park, P.W.; Kil, J.K.; Kung, H.H.; Kung, M.C. NO decomposition over sodium-promoted cobalt oxide. Catal. Today 1998, 42, 51-60. [CrossRef] 
15. Neurock, M. Theory-Aided Catalyst Design. In Design of Heterogeneous Catalysts; Wiley-VCH Verlag GmbH \& Co. KGaA: Weinheim, Germany, 2009; pp. 231-258. [CrossRef]

16. Kotarba, A.; Kruk, I.; Sojka, Z. Energetics of Potassium Loss from Styrene Catalyst Model Components: Reassignment of K Storage and Release Phases. J. Catal. 2002, 211, 265-272. [CrossRef]

17. Bieniasz, W.; Trębala, M.; Sojka, Z.; Kotarba, A. Irreversible deactivation of styrene catalyst due to potassium loss-Development of antidote via mechanism pinning. Catal. Today 2010, 154, 224-228. [CrossRef]

18. Grzybek, G.; Wójcik, S.; Legutko, P.; Gryboś, J.; Indyka, P.; Leszczyński, B.; Kotarba, A.; Sojka, Z. Thermal stability and repartition of potassium promoter between the support and active phase in the $\mathrm{K}-\mathrm{Co}_{2.6} \mathrm{Zn}_{0.4} \mathrm{O}_{4} \mid \alpha-\mathrm{Al}_{2} \mathrm{O}_{3}$ catalyst for $\mathrm{N}_{2} \mathrm{O}$ decomposition: Crucial role of activation temperature on catalytic performance. Appl. Catal. B 2017, 205, 597-604. [CrossRef]

19. Cheng, H.; Huang, Y.; Wang, A.; Li, L.; Wang, X.; Zhang, T. $\mathrm{N}_{2} \mathrm{O}$ decomposition over K-promoted Co-Al catalysts prepared from hydrotalcite-like precursors. Appl. Catal. B 2009, 89, 391-397. [CrossRef]

20. Kotarba, A.S.G.; Ciura, K.; Indyka, P.; Grybos, J.; Grzybek, G.; Legutko, P.; Stelmachowski, P.; Sojka, Z. Alkali Promotion for Enhancing the Activity of Bulk and Supported Cobalt Spinel Catalysts for Low-Temperature $\mathrm{deN}_{2} \mathrm{O}, \mathrm{KRAcat}$ de $\mathrm{N}_{2} \mathrm{O}$. In Proceedings of the International Thematic Workshop KRACat-deN $\mathrm{N}_{2} \mathrm{O}$, Krakow, Poland, 4-6 May 2016..

21. Cheng, J.; Wang, X.; Yu, J.; Hao, Z.; Xu, Z.P. Sulfur-Resistant NO Decomposition Catalysts Derived from Co-Ca/Ti-Al Hydrotalcite-like Compounds. J. Phys. Chem. C 2011, 115, 6651-6660. [CrossRef]

22. Haneda, M.; Nakamura, I.; Fujitani, T.; Hamada, H. Catalytic Active Site for NO Decomposition Elucidated by Surface Science and Real Catalyst. Catal. Surv. Asia 2005, 9, 207-215. [CrossRef]

23. Winter, E.R.S. The catalytic decomposition of nitric oxide by metallic oxides. J. Catal. 1971, 22, $158-170$. [CrossRef]

24. Tsujimoto, S.; Masui, T.; Imanaka, N. Fundamental Aspects of Rare Earth Oxides Affecting Direct NO Decomposition Catalysis. Eur. J. Inorg. Chem. 2015, 2015, 1524-1528. [CrossRef]

25. Hong, W.-J.; Iwamoto, S.; Hosokawa, S.; Wada, K.; Kanai, H.; Inoue, M. Effect of Mn content on physical properties of $\mathrm{CeO}_{\mathrm{x}}-\mathrm{MnOy}$ support and $\mathrm{BaO}-\mathrm{CeO}_{\mathrm{x}}-\mathrm{MnOy}$ catalysts for direct $\mathrm{NO}$ decomposition. J. Catal. 2011, 277, 208-216. [CrossRef]

26. Falsig, H.; Bligaard, T.; Christensen, C.H.; Nørskov, J.K. Direct NO decomposition over stepped transition-metal surfaces. Pure Appl. Chem. 2007, 79, 1895-1903. [CrossRef]

27. Jakubek, T.; Kaspera, W.; Legutko, P.; Stelmachowski, P.; Kotarba, A. Surface versus bulk alkali promotion of cobalt-oxide catalyst in soot oxidation. Catal. Commun. 2015, 71,37-41. [CrossRef]

28. Niemantsverdriet, J.W. Spectroscopy in Catalysis: An Introduction; Willey: Hoboken, NJ, USA, 2007. [CrossRef]

29. Raghuvanshi, S.; Mazaleyrat, F.; Kane, S.N. $\mathrm{Mg}_{1-x} \mathrm{Zn}_{\mathrm{x}} \mathrm{Fe}_{2} \mathrm{O}_{4}$ nanoparticles: Interplay between cation distribution and magnetic properties. AIP Adv. 2017, 8, 047804. [CrossRef]

30. Kovanda, F.; Rojka, T.; Dobešová, J.; Machovič, V.; Bezdička, P.; Obalová, L.; Jirátová, K.; Grygar, T. Mixed oxides obtained from Co and Mn containing layered double hydroxides: Preparation, characterization, and catalytic properties. J. Solid State Chem. 2006, 179, 812-823. [CrossRef]

31. Deraz, N.M. Formation and Characterization of Cobalt Aluminate Nano-Particles. Int. J. Electrochem. Sci. 2013, 8, 4036-4046.

32. Scofield, J.H. Hartree-Slater subshell photoionization cross-sections at 1254 and 1487 eV. J. Electron. Spectrosc. Relat. Phenom. 1976, 8, 129-137. [CrossRef]

33. Obalová, L.; Pacultová, K.; Balabánová, J.; Jirátová, K.; Bastl, Z.; Valášková, M.; Lacný, Z.; Kovanda, F. Effect of $\mathrm{Mn} / \mathrm{Al}$ ratio in $\mathrm{Co}-\mathrm{Mn}-\mathrm{Al}$ mixed oxide catalysts prepared from hydrotalcite-like precursors on catalytic decomposition of $\mathrm{N}_{2} \mathrm{O}$. Catal. Today 2007, 119, 233-238. [CrossRef]

34. Obalová, L.; Karásková, K.; Jirátová, K.; Kovanda, F. Effect of potassium in calcined Co-Mn-Al layered double hydroxide on the catalytic decomposition of $\mathrm{N}_{2}$ O. Appl. Catal. B 2009, 90, 132-140. [CrossRef]

35. Biesinger, M.C.; Payne, B.P.; Grosvenor, A.P.; Lau, L.W.M.; Gerson, A.R.; Smart, R.S.C. Resolving surface chemical states in XPS analysis of first row transition metals, oxides and hydroxides: $\mathrm{Cr}, \mathrm{Mn}, \mathrm{Fe}, \mathrm{Co}$ and Ni. Appl. Surf. Sci. 2011, 257, 2717-2730. [CrossRef]

36. Gautier, J.L.; Rios, E.; Gracia, M.; Marco, J.F.; Gancedo, J.R. Characterisation by X-ray photoelectron spectroscopy of thin $\mathrm{Mn}_{\mathrm{x}} \mathrm{Co}_{3-\mathrm{x}} \mathrm{O}_{4}(1 \geq \mathrm{x} \geq 0)$ spinel films prepared by low-temperature spray pyrolysis. Thin Solid Films 1997, 311, 51-57. [CrossRef] 
37. Todorova, S.; Kolev, H.; Holgado, J.P.; Kadinov, G.; Bonev, C.; Pereñíguez, R.; Caballero, A. Complete n-hexane oxidation over supported Mn-Co catalysts. Appl. Catal. B 2010, 94, 46-54. [CrossRef]

38. Zhou, M.; Cai, L.; Bajdich, M.; García-Melchor, M.; Li, H.; He, J.; Wilcox, J.; Wu, W.; Vojvodic, A.; Zheng, X. Enhancing Catalytic $\mathrm{CO}$ Oxidation over $\mathrm{Co}_{3} \mathrm{O}_{4}$ Nanowires by Substituting $\mathrm{Co}^{2+}$ with $\mathrm{Cu}^{2+}$. ACS Catal. 2015, 5, 4485-4491. [CrossRef]

39. Chen, Z.; Kronawitter, C.X.; Koel, B.E. Facet-dependent activity and stability of $\mathrm{Co}_{3} \mathrm{O}_{4}$ nanocrystals towards the oxygen evolution reaction. PCCP 2015, 17, 29387-29393. [CrossRef]

40. Bhatnagar, A.; Jain, A.K. A comparative adsorption study with different industrial wastes as adsorbents for the removal of cationic dyes from water. J. Colloid Interface Sci. 2005, 281, 49-55. [CrossRef]

41. Kim, S.C.; Shim, W.G. Catalytic combustion of VOCs over a series of manganese oxide catalysts. Appl. Catal. B 2010, 98, 180-185. [CrossRef]

42. Obalová, L.; Maniak, G.; Karásková, K.; Kovanda, F.; Kotarba, A. Electronic nature of potassium promotion effect in $\mathrm{Co}-\mathrm{Mn}-\mathrm{Al}$ mixed oxide on the catalytic decomposition of $\mathrm{N}_{2} \mathrm{O}$. Catal. Commun. 2011, 12, 1055-1058. [CrossRef]

43. Klyushina, A.; Pacultová, K.; Karásková, K.; Jirátová, K.; Ritz, M.; Fridrichová, D.; Volodarskaja, A.; Obalová, L. Effect of preparation method on catalytic properties of Co-Mn-Al mixed oxides for $\mathrm{N}_{2} \mathrm{O}$ decomposition. J. Mol. Catal. A Chem. 2016, 425, 237-247. [CrossRef]

44. Santos, V.P.; Soares, O.S.G.P.; Bakker, J.J.W.; Pereira, M.F.R.; Órfão, J.J.M.; Gascon, J.; Kapteijn, F.; Figueiredo, J.L. Structural and chemical disorder of cryptomelane promoted by alkali doping: Influence on catalytic properties. J. Catal. 2012, 293, 165-174. [CrossRef]

45. Becerra, M.E.; Arias, N.P.; Giraldo, O.H.; López Suárez, F.E.; Illán Gómez, M.J.; Bueno López, A. Soot combustion manganese catalysts prepared by thermal decomposition of $\mathrm{KMnO}_{4}$. Appl. Catal. B 2011, 102, 260-266. [CrossRef]

46. Da Costa-Serra, J.F.; Chica, A. Catalysts based on Co-Birnessite and Co-Todorokite for the efficient production of hydrogen by ethanol steam reforming. Int. J. Hydrog. Energy 2018, 43, 16859-16865. [CrossRef]

47. Obalová, L.; Karásková, K.; Wach, A.; Kustrowski, P.; Mamulová-Kutláková, K.; Michalik, S.; Jirátová, K. Alkali metals as promoters in Co-Mn-Al mixed oxide for $\mathrm{N}_{2} \mathrm{O}$ decomposition. Appl. Catal. A 2013, 462-463, 227-235. [CrossRef]

48. Imanaka, N.; Masui, T. Advances in direct $\mathrm{NO}_{x}$ decomposition catalysts. Appl. Catal. A 2012, 431-432, 1-8. [CrossRef]

49. Smoláková, L.; Frolich, K.; Troppová, I.; Kutálek, P.; Kroft, E.; Čapek, L. Determination of basic sites in Mg-Al mixed oxides by combination of TPD- $\mathrm{CO}_{2}$ and $\mathrm{CO}_{2}$ adsorption calorimetry. J. Therm. Anal. Calorim. 2017, 127, 1921-1929. [CrossRef]

50. Maniak, G.; Stelmachowski, P.; Kotarba, A.; Sojka, Z.; Rico-Pérez, V.; Bueno-López, A. Rationales for the selection of the best precursor for potassium doping of cobalt spinel based $\operatorname{deN}_{2} \mathrm{O}$ catalyst. Appl. Catal. B 2013, 136-137, 302-307. [CrossRef]

51. Gálvez, M.E.; Ascaso, S.; Stelmachowski, P.; Legutko, P.; Kotarba, A.; Moliner, R.; Lázaro, M.J. Influence of the surface potassium species in $\mathrm{Fe}-\mathrm{K} / \mathrm{Al}_{2} \mathrm{O}_{3}$ catalysts on the soot oxidation activity in the presence of $\mathrm{NO}_{\mathrm{x}}$. Appl. Catal. B 2014, 152-153, 88-98. [CrossRef]

52. Borowiecki, T.; Denis, A.; Rawski, M.; Gołębiowski, A.; Stołecki, K.; Dmytrzyk, J.; Kotarba, A. Studies of potassium-promoted nickel catalysts for methane steam reforming: Effect of surface potassium location. Appl. Surf. Sci. 2014, 300, 191-200. [CrossRef]

53. Gimenez, P.; Fereres, S. Effect of Heating Rates and Composition on the Thermal Decomposition of Nitrate Based Molten Salts. Energy Procedia 2015, 69, 654-662. [CrossRef]

54. Kaspera, W.; Wojas, J.; Molenda, M.; Kotarba, A. Parallel migration of potassium and oxygen ions in hexagonal tungsten bronze-Bulk diffusion, surface segregation and desorption. Solid State Ion. 2016, 297, 1-6. [CrossRef]

55. Haneda, M.; Tsuboi, G.; Nagao, Y.; Kintaichi, Y.; Hamada, H. Direct Decomposition of NO Over Alkaline Earth Metal Oxide Catalysts Supported on Cobalt Oxide. Catal. Lett. 2004, 97, 145-150. [CrossRef]

56. Hong, W.-J.; Iwamoto, S.; Inoue, M. Direct NO decomposition over a Ce-Mn mixed oxide modified with alkali and alkaline earth species and $\mathrm{CO}_{2}$-TPD behavior of the catalysts. Catal. Today 2011, 164, 489-494. [CrossRef] 
57. Palomares, E.; Uzcátegui, A.; Franch, C.; Corma, A. Multifunctional catalyst for maximizing $\mathrm{NO}_{\mathrm{x}}$ oxidation/storage/reduction: The role of the different active sites. Appl. Catal. B 2013, 142-143, 795-800. [CrossRef]

58. Haneda, M.; Kintaichi, Y.; Hamada, H. Reaction mechanism of NO decomposition over alkali metal-doped cobalt oxide catalysts. Appl. Catal. B 2005, 55, 169-175. [CrossRef]

59. Haneda, M.; Hamada, H. Recent progress in catalytic NO decomposition. Comptes Rendus Chim. 2016, 19, 1254-1265. [CrossRef]

60. Zhu, J.; Thomas, A. Perovskite-type mixed oxides as catalytic material for NO removal. Appl. Catal. B 2009, 92, 225-233. [CrossRef]

61. Jabłońska, M.; Palomares, A.E.; Chmielarz, L. NOx storage/reduction catalysts based on $\mathrm{Mg} / \mathrm{Zn} / \mathrm{Al} / \mathrm{Fe}$ hydrotalcite-like materials. Chem. Eng. J. 2013, 231, 273-280. [CrossRef]

(C) 2019 by the authors. Licensee MDPI, Basel, Switzerland. This article is an open access article distributed under the terms and conditions of the Creative Commons Attribution (CC BY) license (http://creativecommons.org/licenses/by/4.0/). 